\title{
Sustainable innovativeness and the triple bottom line: \\ The role of organizational time perspective
}

\section{Authors}

Annachiara Longoni, (ESADE Business School, Ramon Llull University, Barcelona, Spain)

Raffaella Cagliano, (School of Management, Politecnico di Milano, Milan, Italy)

Article published in Journal of Business Ethics

Please cite as: Longoni, A., \& Cagliano, R. (2018). Sustainable innovativeness and the triple bottom line: The role of organizational time perspective. Journal of Business Ethics, 151(4), 1097-1120. https://doi.org/10.1007/s10551-016-3239-y 


\title{
Sustainable innovativeness and the triple bottom line: The role of organizational time perspective
}

\begin{abstract}
This paper studies the influence of an organization's time perspective on triple bottom line deployment through sustainable innovativeness. Although academics increasingly consider sustainable innovation to be an essential element in deploying the triple bottom line, the degree of an organization's sustainable innovativeness remains limited. Using ten inductive case studies based on the triangulation of data from multiplerespondent interviews and secondary data, this study shows that an organization's time perspective plays a crucial role in explaining the organization's degree of sustainable innovativeness and improvement of triple bottom line outcomes. Specifically, organizations with a longer planning horizon, higher tolerance of uncertainty and greater ability to learn from the past develop a higher and increasing degree of sustainable innovativeness, allowing trade-offs between triple bottom line dimensions to be mitigated.
\end{abstract}

Keywords: triple bottom line, organizational time perspective, sustainable innovativeness

\section{Introduction}

A growing number of organizations have been integrating environmental and social responsibilities into their business strategies alongside more traditional business imperatives, such as profit maximization, cost reduction, revenue growth, and quality improvement (Porter and Kramer, 2006; McKinsey, 2013). Accordingly, recent business ethics studies point out that it is a moral responsibility for ethical firms to balance social and environmental performance together with their economic performance (e.g., Becker, 2012; Florea et al., 2013). Initially, business ethics studies focused on social issues concerning human beings and their needs, investigating how organizations could deploy their responsibility to 'do good' or to 'create shared-value' in developed and developing societies (e.g., Singhapakdi et al., 1996; Joyner and Paine, 2002). More recently, such 
ethical and moral responsibility has been extended considering environmental ethics (e.g., Sadler-Smith, 2013; Lubin and Esty, 2010), which is the sub-field of ethical studies extending the traditional anthropocentric field of ethics providing moral standing to nonhuman entities including animals, plants, and ecosystems (e.g., Leopold, 1949). This holistic view of business ethics requires to embrace sustainability development in terms of triple bottom line, integrating social, environmental and economic responsibilities (Elkington, 1994).

The holistic view of business ethics and the triple bottom line approach challenge organizations on several sides: Managers are confronted with tensions among interrelated temporal aspects, i.e., meeting present needs without compromising future needs (Lozano, 2008) and among complex and interrelated social, environmental, and economic issues (Hahn et al., 2014). Within this framework, social sustainability is defined as the ability to positively affect workers' welfare, well-being and safety as well as community development (Klassen and Vereecke, 2012); environmental sustainability is defined as the reduction of natural resource consumption and pollutant emissions and the elimination of organizational activities that can degrade the ecosystem (Vachon and Mao, 2008); and economic sustainability is defined as the ability to generate consistent profit over time (Steurer and Konrad, 2009; Vachon and Mao, 2008).

Recent publications suggest that to develop an organization's ethical responsibility towards the three dimensions of the triple bottom line and to overcome possible tensions and enhance synergies, organizations must seek innovative solutions, particularly radical innovations (e.g., Hahn et al., 2014; Gao and Bansal, 2013; Pagell and Shevchenko, 2014). Accordingly, developing sustainable innovations has been defined as a necessary responsibility of organizations to contribute to the future of the society and the natural environment (Grinbaum and Groves, 2013). Nevertheless, organizations' adoption of 
radical sustainable innovations remains limited (Pinkse and Kolk, 2010; Pagell and Shevchenko, 2014), perhaps because sustainable radical innovations require companies to adopt a different time perspective than the typical time horizon of traditional organizations' initiatives (Held, 2001; Hahn et al., 2014) and have uncertain results (Pinkse and Kolk, 2010). The relevance of an organization's time perspective with respect to its response to environmental and social responsibilities has been demonstrated by previous studies (Alas, 2006; Das, 2005; Fritzsche, 1991; Slawinski and Bansal, 2012). However, only rarely have these studies considered multiple dimensions of the triple bottom line simultaneously or focused on the degree of organizations' sustainable innovativeness.

In this paper, we investigate the relationship between an organization's time perspective, the degree of innovativeness of its adopted sustainable innovations, and their impact on the triple bottom line. Specifically, this research is set out to investigate: (1) How the organization's time perspective is related to its degree of sustainable innovativeness; and (2) How the degree of sustainable innovativeness, based on different time perspectives, affect the improvement of triple bottom line outcomes. Doing so, this paper contributes to the understanding of how a holistic business ethics approach related to the three dimensions of the triple bottom line can be achieved through sustainable innovativeness: Firstly, we explore different organizational time perspectives in the development of sustainability issues; secondly, we examine the relationship between an organization's time perspective and its sustainable innovativeness; finally, we investigate the impact of an organization's time perspective, associated with sustainable innovativeness, on triple bottom line outcomes.

In the next section, we present the state of the art regarding sustainable innovations and the role of an organization's time perspective. Subsequently, we provide details 
regarding our methodology. Our results are then presented and discussed to demonstrate the role of the organization's time perspective in the development of sustainable innovativeness and the improvement of triple bottom line outcomes. Finally, the paper concludes with a discussion of the study's main implications and limitations.

\section{Literature review}

\subsection{Sustainable innovativeness}

Early studies on sustainability focused on social or environmental issues (Fritzsche, 1991; Kleindorfer et al., 2005). However, organizations have increasingly integrated economic, environmental and social responsibilities in line with a holistic view of business ethics and, in operational terms, with the triple bottom line approach (Elkington, 1994; Bettley and Burnley, 2008; Gimenez et al., 2012; Pagell and Gobeli, 2009; Gao and Bansal, 2013; Hahn et al., 2010; Hahn et al., 2015). The literature has proposed two main views in interpreting the triple bottom line: a win-win perspective and a trade-offs perspective. The win-win perspective - also referred to as business case perspective - assumes that benefits in two or more dimensions of the triple bottom line can be achieved simultaneously since synergistic effects can be exploited. In contrast, the trade-offs perspective focuses on those cases in which synergies do not exist and thus "address[es] those situations in which corporate contributions to sustainable development can only be achieved if one accepts a compromise between at least two sustainability dimensions that are in conflict with each other” (Hahn et al., 2010, p. 20). Many authors theoretically support the business case perspective (e.g., Christmann, 2000) and empirically answer the question of whether (and under what conditions) superior environmental and/or social performance pays off financially for organizations (Margolis and Walsh, 2003; Orlitzky et al., 2003). However, the empirical literature offers also numerous cases of companies 
that face trade-offs between economic and non-economic performance (e.g., Kolk, 2012; Lee, 2010; Wu and Pagell, 2011). Some authors also criticize the business case perspective, arguing that it considers economic objectives to be dominant over environmental and social aspects (Owen et al., 2000; Owen et al., 2001). Instead, different views - such as the stakeholder accountability perspective — place much more emphasis on the need to prioritize environmental and social goals by proactively engaging with stakeholders (Brown and Fraser, 2006).

The recent literature suggests that organizations must seek innovative solutions to transcend and reconcile trade-offs and tensions - when they exist - and enhance synergies in order to effectively address multiple dimensions of the triple bottom line (Gao and Bansal, 2013). However, numerous authors have noted that the triple bottom line is a fundamentally new way of thinking and that organizations are required to adopt sustainable innovations in their business processes (Pagell and Shevchenko, 2014; Hahn et al., 2015). A key issue here is whether these innovations should be radical or whether they can be incremental (Pinkse and Kolk, 2010), thus pointing to the degree of sustainable innovativeness. Innovativeness is often used to measure the degree of "newness" of an innovation (Garcia and Carltone, 2002). In this regard, radical innovations are considered to have a high degree of newness, as they destroy the old system and structurally change it; in contrast, incremental solutions are considered to have a low degree of newness, as they only partially change the old way of working. There are different aspects defining innovativeness. One key aspect is technological change (Garcia and Carltone, 2002). Innovations characterized by a high degree of technological change are those that provide a new technology that structurally changes the previous system. Technological change bears an extremely relevant relation to sustainable innovations. From a theoretical perspective, Hahn et al. (2015) suggest that 
technological changes play a crucial role in the development of new business models, products and ways of working in order to deploy the triple bottom line. Accordingly, studying organizational responses to climate change, Pinkse and Kolk (2010) assert that the international debate increasingly points to the role of technological innovations, and they explore some key challenges that organizations face in developing such innovations.

Another aspect that must be considered when analyzing the degree of innovativeness of sustainable innovations is the scope of the innovation impact (Klassen and Vereecke, 2012). To actually change the status quo, sustainable innovations must introduce radical changes not only at the organizational but also at the societal level (Hahn et al., 2015). Organizations can invest in becoming more sustainable; however, sustainable development is a society-level matter: "Individual organizations simply contribute to the large system in which sustainability may or may not be achieved” (Jennings and Zandbergen 1995, p. 1023). Accordingly, the stakeholder theory (Freeman, 1984) points toward a range of stakeholders that are affected by organizational activities spanning from the internal organizational level - within a firm's own operations - to the societal level, which includes entities ranging from the firm's suppliers and customers to stakeholders such as communities, regulators, and NGOs. Sustainable innovations with a high degree of innovativeness are those that have an impact at both the organizational and societal levels, reaching organization's relevant stakeholders.

\subsection{Organizational time perspective and sustainable innovativeness}

Recent studies suggest that an organization's time perspective may influence the way in which the triple bottom line is developed in the organization (e.g., Slawinski and Bansal, 2012; Hahn et al., 2015). In this view, time is not objective; instead, what time is and how it is experienced differ within and across individuals, organizations, cultures, geographies, 
and societies (Adam, 1994; Bluedorn and Waller, 2006). Indeed, time is not unitary, as in the traditional clock-time view; rather, it is perceived in relation to different aspects. Specifically, in this study, we focus on the time perspective of organizations in relation to social and environmental issues. Relevant aspects suggested to characterize such a time perspective are organizations' planning horizon, tolerance of uncertainty and ability to learn from the past (Slawinski and Bansal, 2012).

\subsubsection{Planning horizon}

Concerning organizations’ planning horizon, the triple bottom line may require a longer time orientation for evaluating investments than the time horizon of traditional firms, which has been criticized for its short-term focus (Held, 2001; Hallstedt et al., 2010). This longer time orientation relates to the different time horizons that are needed to evaluate investments with regard to the economic dimension on the one hand and the environmental and social dimensions on the other (Hahn et al., 2015). While the economic dimension emphasizes short-term financial objectives, environmental protection and social equity require to firms to focus more attention on long-term concerns. A long-term planning horizon is necessary to consider the interests of stakeholders and the long-term consequences of firms' decisions (Broome, 1994); however, a long-term horizon and the involvement of different stakeholders also have the side effect that initiatives take much longer to materialize, leading to a much slower response, especially in terms of economic performance improvement (Slawinski and Bansal, 2012).

Indeed, prior research suggests that sustainable innovations, particularly radical innovations, have a negative or uncertain impact on profit in the short term (e.g., Hahn et al., 2010; Pinkse and Kolk, 2010; Winn et al., 2012). Radical social innovations often require organizations to make significant ongoing short-term investments that consume 
economic or other resources, while radical environmental innovations are typically fixed investments that have a negative impact on short-term financial performance (Pagell and Shevchenko, 2014; Wu and Pagell, 2011). These negative economic impacts in the short term often prevent organizations from adopting radical sustainable innovations.

\subsubsection{Tolerance of uncertainty}

Companies also appear to be reticent to implementing radical and structural sustainable innovations because of their uncertain results (Rugman and Verbeke, 1998; Pinkse and Kolk, 2010). Such uncertainty arises because radical innovations (e.g., structural technological changes) strongly depend on long-term investments in research and development, a process in which the outcome is always uncertain (Gallagher et al., 2006; Wellington et al., 2007). Further, all of this must occur in a setting in which viable markets and concomitant infrastructure are (as yet) absent and in which uncertainty about technological possibilities exists (Pinkse and Kolk, 2010). As a consequence, economic outcomes are uncertain in many cases, particularly within the time horizon of the evaluation of the investment.

However, the literature suggests that traditional approaches to evaluating uncertain investments, such as the Net Present Value (NPV) approach, capture the possibility that actual returns might be lower than expected but do not appropriately reflect the possibility that actual returns might be higher (Cornelius et al., 2005). Specifically, the NPV approach fails to consider the value of flexibility and opportunities that sustainability investments may engender (Husted, 2005). Accordingly, recent contributions have considered sustainability investments in terms of real options (e.g., Husted, 2005; Bush and Hoffman, 2009; Cassimon et al., 2015). The authors of these contributions suggest that the price of the sustainability option is the cost of the investment, while its value 
consists in the assets that it creates and the right to exploit them (Husted, 2005). However, such value is difficult to estimate. If they simply consider the cost and revenues related to investments, organizations will underinvest in them. Instead, if they consider the value of a project in terms of the access to resources and flexibility provided, organizations may change their evaluation (Husted, 2005). Further, Cassimon et al. (2015) suggest that unless organizations perceive the opportunity cost of waiting, which is related, for example, to lost opportunities to engage with stakeholders and the associated decline in their relationship, they tend to postpone such investments. Thus, differences in the level of organizations' tolerance of uncertainty in their evaluation of the value and opportunity cost of waiting with respect to sustainability investments may lead organizations to adopt sustainable innovations to different extents.

\subsubsection{Ability to learn from the past}

Studies comparing environmental and social development have often considered organizational time perspective in terms of organizations' ability to learn from the past and to link past, present, and future decisions (Ashkanasy et al., 2004; Alas, 2006). This research shows that past-oriented individuals and collectives recall and show appreciation for prior learning, obligations, and traditions when making social- and environmentalrelated decisions (Keough et al., 1999). Specifically, in relation to radical innovations, the ability to learn from the past has often been suggested as fundamental. Radical innovations are determined through path-dependent innovation processes, and different phases shape invention, development and implementation in an evolutionary way (Garud et al., 2013).

However, focusing only on the past may be detrimental to organizations’ future challenges and innovations if this information is used only to replicate past decisions. 
Therefore, the ability to learn from the past should feed current and future actions with past knowledge and experience but through a higher level of learning ability. Argiris and Schon (1983) use the metaphors of single-loop and double-loop learning to explain this situation. In single-loop learning, monitoring activities are performed and actions are taken according to the initial evaluation criteria. In contrast, in a double-loop learning, evaluation criteria may change according to the current and future situation. Past practices are questioned, new assumptions about the organization are raised, and significant changes are considered. Thus, these authors suggest that a double-loop learning process can improve the innovation process.

Concerning sustainability specifically, Slawinski and Bansal (2012) show that organizations that learn from the past are able to connect learned information to future actions and are likely to coordinate and learn to develop broader solutions with respect to climate change. Learning from the past and connecting learned information to a more sustainable vision of the future may bring organizations closer to addressing the many challenges associated with sustainability.

In this paper, we focus on an organization's time perspective to investigate its degree of sustainable innovativeness and improvement in triple bottom line outcomes. Specifically, building on Slawinski and Bansal (2012), we define organizational time perspective based on three abovementioned aspects identified in the literature: planning horizon, tolerance of uncertainty and ability to learn from the past. Slawinski and Bansal (2012) investigate the role of organizational time perspective in organizational responses to climate change. The authors find that organizations that favor a cyclical time perspective (i.e., organizations with a long time horizon, consideration of past events and tolerance of uncertainty) develop broader responses to climate change in terms of the breadth and impact on stakeholders than organizations that favor a linear time perspective 
(i.e., organizations with a short time horizon, little consideration of the past and low tolerance of uncertainty). However, they do not discuss how organizational time perspective is related to different degrees of sustainable innovativeness and impacts on triple bottom line outcomes.

Thus, we aim to answer to the following research questions:

RQ1. How is an organization's time perspective related to its degree of sustainable innovativeness?

RQ2. How does organizations' degree of sustainable innovativeness, based on different time perspectives, affect the improvement of triple bottom line outcomes?

\section{Methodology}

To ground our theoretical insights, we applied an inductive methodology to address our research questions (Gioia et al., 2013; Corbin and Strauss, 2008). While deductive studies aim to test hypotheses, our study aims to generate new theory through an inductive approach. Specifically, we conducted multiple case studies in the Italian food industry.

\subsection{Sample selection}

Purposeful, non-random samples based on theoretical underpinnings are suggested for qualitative studies to increase content validity and generalizability (Eisenhardt, 1989). Thus, selection was performed to control for extraneous factors and increase generalizability. For example, in accordance with suggestions in the literature that possible differences in terms of regulations, enforcement, and customers at the industry and country levels influence the commitment to sustainability (e.g., Campbell, 2007; Chen et al., 2015; Ho et al., 2012), we focused on a single industry in a single country. We selected the food industry because it is particularly active in the improvement of triple bottom line outcomes (e.g., Aiking and de Boer, 2004; Maloni and Brown, 2006). Further, 
organizations' size is suggested to be an important determinant of sustainability investments at the firm level (Berrone et al., 2013; Tan and Peng, 2003); thus, to increase the generalizability of our results, we included organizations of different sizes in our sample.

The sample frame was a panel of organizations committed to the development of the triple bottom line. The organizations were identified by using a range of secondary data (e.g., organizations producing sustainability reports and having GRI rankings). Suggestions regarding the number of cases to use in multiple case studies vary; however, Eisenhardt (1989) suggests seven cases as the maximum that a person can mentally process. Yin (1994) and others are more circumspect with respect to hard numbers and instead suggest that data should be collected until saturation is achieved. For these reasons, the final sample comprises ten cases. Table 1 summarizes the main information on the organizations in the sample. To protect the identities of the organizations, we renamed them by using alphabetical letters.

Table 1: Main information for the sample

\begin{tabular}{|c|c|c|}
\hline Organization & Product produced & Size (2010) \\
\hline Company A & Diversified food production & 1,343 mln€ sales \\
& & 3,000 employees \\
\hline Company B & Diversified food production & 999 mln€ \\
& & 1,483 employees \\
\hline Company C & Pasta & 4.171 mln€ \\
& & 5,000 employees \\
\hline Company D & Pasta & 343 mln€ \\
& & 741 employees \\
\hline Company E & Milk and cheese & 900 mln€ \\
& & 2,000 employees \\
\hline Company F & Milk and cheese & 500 mln€ \\
& & 320 employees \\
\hline Company G & Milk and cheese & 94.6 mln€ \\
& & 183 employees \\
\hline Company H & Coffee & 283.4 mln€ \\
& & 700 employees \\
\hline Company I & Vegetables & 178.5 mln€ \\
& & 439 employees \\
\hline Company L & Water & 137 mln€ \\
& & 360 employees \\
\hline
\end{tabular}




\subsection{Data sources}

The data were collected over a period ranging from 2005 to 2013. The earliest year, 2005, was chosen because around that year the ten organizations in the sample started to formalize the deployment of a corporate sustainability strategy in relation to all three dimensions of the triple bottom line. The final year, 2013, is the last year for which data have been collected. We considered this time range to be sufficient for investigating the long-term impact of the organizations' time perspective and sustainable innovations on their triple bottom line outcomes. We ensured the reliability of our findings by drawing data from multiple data sources, including in-depth interviews with multiple respondents and secondary sources. Each of these sources is described below and listed in Appendix A.

\section{Multiple-respondent interviews}

Interviews were conducted in 2010-2011. The interviews were based on a semistructured protocol investigating the organizations' adopted sustainable innovations, time perspective, and achieved results (Eisenhardt, 1989). We essentially asked the respondents to narrate their organizations' path toward sustainability development since 2005, particularly, the sustainable innovations adopted, the decision-making process and criteria used for innovation adoption, and the successes and failures in adopting or failing to adopt innovations (see Appendix B). In each organization, at least three informants were interviewed. After contacting the company by phone and checking their interest in participating in the study, we identified the best informants with the support of the contact person. In particular, we asked to interview people who are involved in the Sustainability Committee or who take part in strategic decisions regarding the deployment of corporate sustainability. Specifically, in most cases, we involved the person in charge of 
sustainability deployment in supply chain-related activities, the Human Resources (HR) manager and the Corporate Social Responsibility (CSR) manager. The interviewees often belonged to the top management team or the highest level of the hierarchy in their functions. Most of the interviews lasted more than 90 minutes. The use of multiple respondents mitigates single respondent bias and increases the odds of capturing organizations' time perspective, view of the triple bottom line, and development through sustainable innovations (Yin, 1994). The interviews were conducted on site (Yin, 1994) by two or three interviewers. After each site visit, each interviewer edited the field notes and checked them for accuracy. Questions arising from the interview notes were answered by interviewees through follow-up e-mails and telephone calls. Furthermore, after conducting the interviews and the analysis, we shared with informants a description of our findings regarding their case to increase interpretative validity.

\section{Secondary sources}

Our secondary sources include mainly annual reports and sustainability reports of the companies interviewed during the period from 2005 to 2013 (see Appendix A). Annual reports and sustainability reports provided information about the organizations' adopted sustainable innovations, their time perspective and the improvement in their triple bottom line outcomes. Further, data on financial performance provided in annual reports were triangulated through the AIDA database, which contains information on Italian companies’ financial performance.

\subsection{Data coding and measurement}


Coding and measurement were performed with the aims of reducing the potential that confirmation bias could influence the results and of increasing descriptive validity and theoretical validity (Strauss and Corbin, 1990).

\section{Measurement of sustainable innovativeness}

To limit the scope of the data collection and to measure more reliable constructs, we focused on sustainable innovations adopted along internal operations and supply chain processes. Specifically, internal operations processes concern manufacturing or service delivery under a firm's direct control, and supply chain processes refer to externaloriented processes related to suppliers and customers. These processes have been shown to be crucial to the improvement of triple bottom line outcomes, as they have a direct impact on the natural environmental, workers and external communities (e.g., Gimenez et al., 2012; Wolf, 2014; Seuring and Muller, 2008; Prajogo and Lai, 2014).

The dimensions that the sustainability literature suggests are relevant in describing sustainable innovations are the degree of technological change (Pinkse and Kolk, 2010; Hahn et al., 2015) and the scope of the impact (Klassen and Vereecke, 2012). Therefore, to define a measure of sustainable innovativeness that captures both dimensions, we built on the innovation literature that defines project innovativeness in terms of a $2 \times 2$ matrix (e.g., Booz et al., 1982; Garcia and Carltone, 2002; Holahan et al., 2014). Traditionally, the two dimensions of the innovation matrix refer to technological uncertainty (i.e., more or less radical changes in the technology) and market uncertainty (i.e., the newness of the market addressed by the innovation). We assert that the level of technological change associated with sustainable innovations is similar to the technological uncertainty dimension, while the scope of the impact is similar to the market uncertainty dimension. 
For this reason, each innovation adopted by the organizations was coded by referring to their level of technological change and scope of impact. While each dimension is assumed to be a continuum across the entire population, the reality of qualitative data is that they are not well suited for continuous coding. Thus, we adopted the following approach:

- Technological change was coded as either a low degree of change (i.e., an innovation that does not structurally modify internal operations and supply chain processes) or a high degree of change (i.e., an innovation that engenders structural changes to internal operations and supply chain processes) (Hellström, 2007).

- Scope of impact was coded to reflect whether innovations occur either at the organizational level only or at both the organizational and societal levels (i.e., internal organization, stakeholders, customers, suppliers, and local community) (Pagell and Shevchenko, 2014; Boons et al., 2013).

The combination of these two dimensions in a 2x2 matrix generated the measure of the degree of sustainable innovativeness. The innovation literature refers to the lower lefthand quadrant as "incremental innovations"; the upper right-hand quadrant as "radical innovations", and the upper left-hand or lower right-hand quadrant of the matrix as "more innovative innovations." We maintained the first two labels; however, we divided the third category into societally innovative and technologically innovative innovations to distinguish the related innovation dimensions. These last two categories, while still having an incremental nature, nevertheless reflect greater newness with respect to at least one of the aspects of sustainable innovativeness. 
Figure 1: Sustainable innovativeness matrix and illustrations from the data

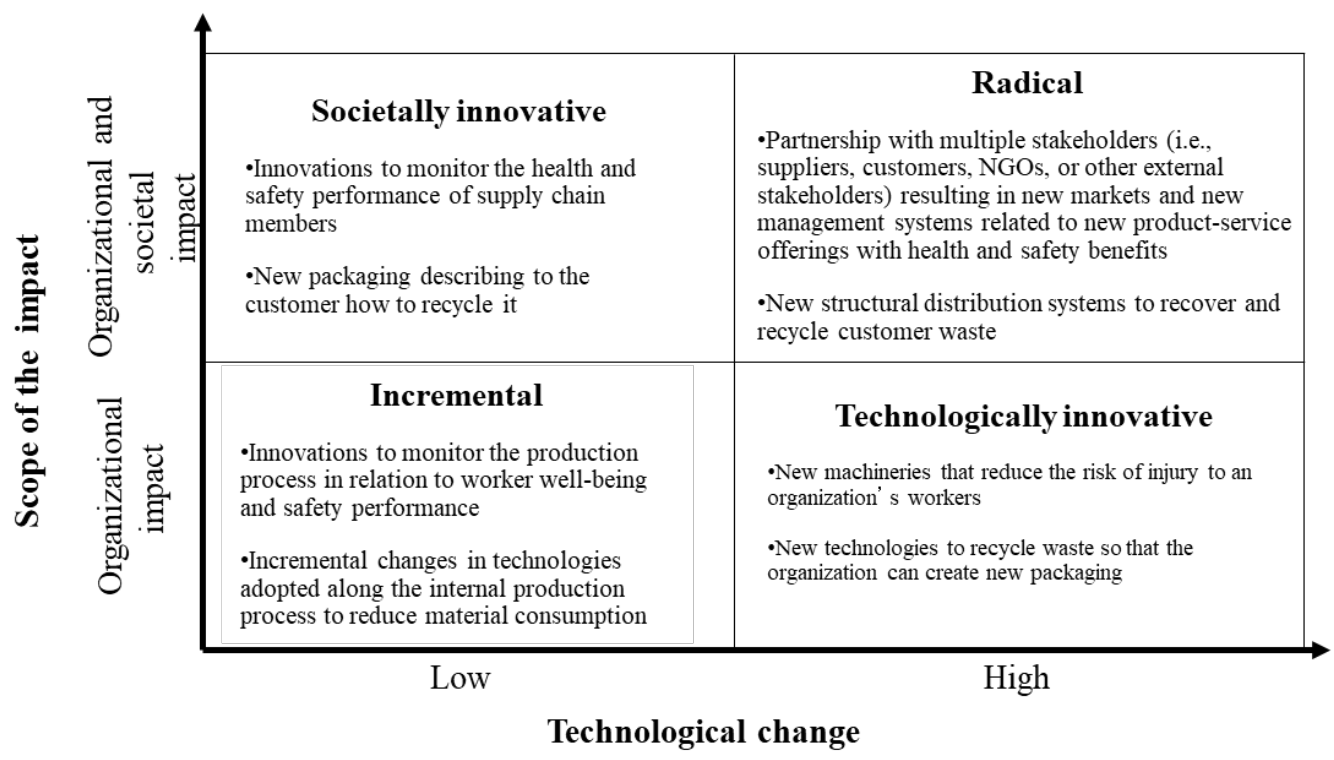

Finally, we evaluated each organization's overall degree of sustainable innovativeness by considering the organizations' sustainable innovation portfolios over three three-year periods - from 2005 to 2007, from 2008 to 2010, and from 2011 to 2013 - and their evolution. We considered three years to be the best time frame to define organizations' sustainable innovation portfolio given that each innovation in the analysis was deployed over a period of at least three years.

Data used to assess this measure were drawn from interviews where we asked numerous questions in order to capture the nature of the innovations that the organization has implemented in relation to sustainability during each period. Further, this information was triangulated with information provided in the organizations’ sustainability reports.

\section{Measurement of organizational time perspective}

In terms of organizational time perspective, the relevant dimensions that have emerged in the sustainability literature are planning horizon, tolerance of uncertainty and ability to learn from the past. We used the definitions provided by Slawinski and Bansal 
(2012) to code our data in relation to these dimensions. Specifically, we used the following definitions:

- Planning horizon refers to the time frame considered by the organization when making decisions, defining goals, planning activities and evaluating results related to its sustainable strategies and investments;

- Tolerance of uncertainty refers to the disposition of the organization to adopt some sustainable innovations even if the associated economic returns are not certain;

- Ability to learn from the past refers to the tendency of the organization to learn from past events in evaluating and developing sustainable innovations.

We assessed these dimensions by using data from both interviews and secondary sources and triangulated them.

\subsection{Data analysis}

The data analysis involved three stages: a within-case analysis, a cross-case analysis, and a theory-building stage (Miles and Huberman, 1994). In the first stage, to increase descriptive validity, multiple data sources and multiple researchers were involved in the analysis to triangulate the information. The first author and two independent trained coders identified the main concepts and attributes related to each organization's time perspective, its sustainable innovativeness and the improvement of its triple bottom line outcomes by combining data from the interviews and secondary sources. Then, they met to consider alternative evaluations concerning the concepts, attributes and assessment of the studied organizations until they all agreed.

In the second stage, in the cross-case analysis, the organizations were grouped based on their time perspective to investigate possible links with the degree of sustainable innovativeness and the improvement of triple bottom line outcomes. Building on a widely 
used method in social science research (e.g., Meier and O’Toole, 2002; Brammer and Millington, 2008), we employed a two-stage methodology to reveal the degree of sustainable innovativeness and the improvement in triple bottom line outcomes in each organization: first, we analyzed similarities and differences among groups of organizations in terms of the organizations' time perspective and degree of innovativeness; then, we analyzed these same groups in relation to the improvement of triple bottom line outcomes.

In the third stage, to increase theoretical validity, we iterated between the data and theory, and the results confirmed that organizations with different time perspectives are characterized by different degrees of innovativeness and different levels of improvement in triple bottom line outcomes.

\section{Findings}

In this section, we describe the three patterns regarding organizational time perspective and sustainable innovativeness that we found among the ten companies in our sample and the related improvement in triple bottom line outcomes. We assessed sustainable innovativeness and organizational time perspective according to section 3.3. The different degrees of sustainable innovativeness associated with the organizations are described in Table 2. We then used our data to show how these three different degrees of sustainable innovativeness are related to distinct time perspectives, which are listed in Table 3. Finally, we used the data to analyze the improvement of triple bottom line outcomes associated with these different groups, as illustrated in Table 7.

In analyzing the interview data and secondary data, we found three overarching patterns regarding the degree of sustainable innovativeness of the organizations in our sample. We labeled the three patterns as follows: higher and increasing innovativeness, 
average and stable innovativeness and lower and decreasing innovativeness. Four organizations (i.e., Companies A, B, C and F) were found to have higher and increasing innovativeness, meaning that the level of sustainable innovativeness associated with their innovations was higher than that of the rest of the sample and that it increased over the years assessed. Adopted initiatives in these companies include societally innovative, technologically innovative and radical innovations. Two organizations (i.e., Companies $\mathrm{D}$ and $\mathrm{H}$ ) were found to be characterized by average and stable innovativeness, where the adopted initiatives include a stable set of societally innovative, technologically innovative and incremental innovations but never radical innovations. Finally, four organizations (i.e., Companies E, G, I and L) showed lower and decreasing innovativeness over the years assessed. These companies adopted technologically 
Table 2: Organizations' sustainable innovativeness

\begin{tabular}{|c|c|c|c|c|}
\hline Constructs & Dimensions & $\begin{array}{l}\text { Higher and increasing } \\
\text { innovativeness } \\
\text { (Companies A, B, C and F) }\end{array}$ & $\begin{array}{l}\text { Average and stable } \\
\text { innovativeness } \\
(\text { Companies } \mathrm{D} \text { and } \mathrm{H})\end{array}$ & $\begin{array}{l}\text { Lower and decreasing } \\
\text { innovativeness } \\
\text { (Companies E, G, I and L) }\end{array}$ \\
\hline \multirow{4}{*}{$\begin{array}{l}\text { Degree of } \\
\text { sustainable } \\
\text { innovativeness* }\end{array}$} & Incremental & Average and decreasing & Average and stable & Lower and increasing \\
\hline & Technologically innovative & Higher and increasing & Lower and stable & Lower and decreasing \\
\hline & Socially innovative & Higher and increasing & Somewhat high and stable & Not adopted \\
\hline & Radical & Higher and increasing & Not adopted & Not adopted \\
\hline
\end{tabular}

* Higher indicates that the percentage of the innovations in the three three-year portfolios of the organization fitting in the sustainable innovativeness category was 1 or more standard deviations above the sample average.

Somewhat above average indicates that the percentage of the innovations in the three three-year portfolios of the organization fitting in the sustainable innovativeness category was half a standard deviation above the sample average.

Average indicates that the percentage of the innovations in the three three-year portfolios of the organization fitting in the sustainable innovativeness category was the sample average.

Somewhat below average indicates that the percentage of the innovations in the three three-year portfolios of the organization fitting in the sustainable innovativeness category was half a standard deviation below the sample average.

Below average indicates that the percentage of the innovations in the three three-year portfolios of the organization fitting in the sustainable innovativeness category was 1 or more standard deviations below the sample average.

Increasing indicates that the percentage of the innovations in the three three-year portfolios of the organization fitting in the category increased over the years assessed. Stable indicates that the percentage of the innovations in the three three-year portfolios of the organization fitting in the category was the same over the years assessed. Decreasing indicates that the percentage of the innovations in the three three-year portfolios of the organization fitting in the category decreased over the years assessed. 
innovative and incremental innovations to a low and decreasing extent over time but never adopted societally innovative and radical innovations.

In our data, we also found that the three groups of organizations characterized by the same degree of sustainable innovativeness also shared a similar time perspective. Specifically, in our sample, we identified three main types of organizational time perspectives: i) a cyclical time perspective, which is characterized by a longer planning horizon, higher tolerance of uncertainty and greater ability to learn from the past (i.e., Companies A, B, C and F); ii) a mixed time perspective, which is characterized by a longer planning horizon, lower tolerance of uncertainty and lower ability to learn from the past (i.e., Companies D and H); iii) and a linear time perspective, which is characterized by a shorter planning horizon, lower tolerance of uncertainty and lower ability to learn from the past (i.e., Companies E, G, I and L).

Table 3: Organizations' time perspective

\begin{tabular}{|c|c|c|c|c|}
\hline Constructs & Dimensions & $\begin{array}{l}\text { Cyclical time perspective } \\
\text { (Companies A, B, C and F) }\end{array}$ & $\begin{array}{l}\text { Mixed time perspective } \\
\text { (Companies D and H) }\end{array}$ & $\begin{array}{l}\text { Linear time } \\
\text { perspective } \\
\text { (Companies E, G, I } \\
\text { and L) }\end{array}$ \\
\hline \multirow{3}{*}{$\begin{array}{l}\text { Organization's } \\
\text { time perspective }\end{array}$} & Planning horizon ${ }^{a}$ & Longer & Longer & Shorter \\
\hline & $\begin{array}{ll}\text { Tolerance } & \text { of } \\
\text { uncertainty }^{\mathrm{b}}\end{array}$ & Higher & Lower & Lower \\
\hline & $\begin{array}{l}\text { Ability to learn } \\
\text { from the past }^{\mathrm{c}}\end{array}$ & Higher & Lower & Lower \\
\hline
\end{tabular}

${ }^{\mathbf{a}}$ Longer refers to whether data from the interviews and sustainability reports reported goals, planning and evaluation activities with a time horizon of 5 years or longer.

Shorter refers to whether data from the interviews and sustainability reports reported goals, planning and evaluation with a time horizon maximum of 5 years.

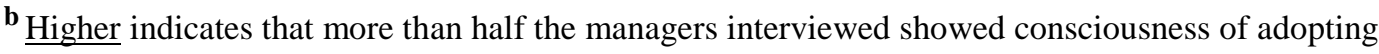
innovations even if the impacts were unclear owing to qualitative evaluations.

Lower refers to whether more than half the managers interviewed referred to the need to know with clarity the impact of sustainable innovations, especially with respect to economic performance, and whether the word "uncertainty" or "uncertain" was used to describe sustainable innovations in the sustainability report to justify the postponement of sustainable investments. 
${ }^{\mathbf{c}}$ Higher indicates that more than half the managers interviewed referred to accumulated past experience in relation to the development of current and future sustainable innovations and that an organization's past decisions (e.g., a subsequent innovation made possible by a previous one, the results of a previous innovation having an impact on a subsequent innovation, the stability of the innovations adopted over time) were mentioned in the sustainability report,.

Lower indicates that managers did not mention past experience in relation to sustainable innovation development.

Organizations with higher and increasing innovativeness adopted a cyclical time perspective, organizations with average and stable innovativeness adopted a mixed time perspective, and organizations with lower and decreasing innovativeness adopted a linear time perspective. In the paragraphs that follow, we provide more evidence on how the different dimensions of organizational time perspective might explain different degrees of sustainable innovativeness and how an organization's time perspective and sustainable innovativeness are related to its level of improvement in triple bottom line outcomes.

\subsection{Planning horizon and scope of sustainable innovations}

The cross-case analysis showed that the analyzed organizations' planning horizon for evaluating sustainability strategies was on average long: in six cases, it was beyond five years, while in four cases, it was up to five years. These different planning horizons may influence the organizations' sustainable innovativeness, particularly with respect to the scope of innovations' impact. Specifically, as shown by comparing Table 2 and Table 3, organizations in our sample with a longer planning horizon are more prone to develop societally innovative initiatives (i.e., Companies A, B, C, F, D and H). In contrast, organizations with a shorter planning horizon do not develop societally innovative initiatives (i.e., Companies E, G, I and L).

Furthermore, Table 4 provides some illustrations from the interview data that clarify how the relationship between planning horizon and societally innovative initiatives arises. For companies with a longer planning horizon, sustainability is a long- 
term challenge, and external stakeholders play a crucial role in improving triple bottom line outcomes. However, the impact of initiatives involving external stakeholders (i.e., societally innovative initiatives) takes longer to manifest than that of organizationoriented initiatives. The long planning horizon of these organizations allows them to take such long-term impacts into account and to emphasize their relevance. For example, as explained by the HSE manager at Company C, consumer behavior plays a crucial role in long-term triple bottom line achievements, and specific innovations are deployed in line with their long-term sustainability plan:

"Our strategy is to build the basis for sustainability for at least the next ten years, and this is related to external stakeholders. Most unsustainable behaviors have been found to be related to consumers. For example, most $\mathrm{CO}_{2}$ emissions are generated at the pasta cooking stage. We can immediately reduce emissions in our production plant, but this would not be enough to achieve sustainability. Awareness and education about consumers' role in sustainability need to be spread. We changed the packaging of our products to provide information about its recyclability but also to provide instructions about more sustainable cocking methods. Our aim is to change consumers' behaviors in the long term."

Another informant, the communication and human resources manager at Company $\mathrm{H}$, noted the difference between short- and long-term sustainability plans, highlighting that the impact on external stakeholders particularly concerns long-term sustainability plans:

"Our sustainability plan has long-term goals covering the next ten years. If we wanted to achieve sustainability in the short term, we could have gone for environmental and social certifications only. But this is not the way to be sustainable in the long term. To do so, it is necessary to act in a way that considers the impact of business activities on the external community.”

Further, she added the following example: 
"We know that the air filtering and closed-loop system is very expensive and that it has diminished our financial performance so far, but we think that such investments will provide us with benefits in the future. [...] In fact, our workers think that we are also doing well for them by improving their working conditions and avoiding negative impacts on the landscape where they live. Therefore, they come to work more motivated, and this is providing an increase in their productivity."

In contrast, organizations with a shorter planning horizon deploy innovations that have effects in the short term and that are focused on internal activities, despite the possible negative drawbacks at the societal level, and they avoid innovations at the societal level that do not fit with their short-term economic goals. For example, the operations manager at Company $\mathrm{G}$ made the following observation:

"If we install a water-cleaning filter and a closed-loop system to reuse water, we will not have any economic benefits in the short term .... We analyzed the convenience in terms of the return on investment of implementing such technology because the community (referring to the local community where the plant is located) asked us to do it, but we learned that it may have a negative economic effect. Therefore, we did not start the project and asked for a dispensation to wait to do it." Accordingly, at the beginning of the interview, she asserted the following:

“The sustainability plan has to be functional with respect to our annual financial goals. When this is not possible, we do not take related actions." 
Table 4: Planning horizon and sustainable innovativeness

\begin{tabular}{|c|c|c|}
\hline Organization & Planning horizon & Illustration from the interview data \\
\hline Company C & High & $\begin{array}{l}\text { Their aim is to establish the basis for building sustainability for at least the next ten years. This long-term perspective both allows and asks them to } \\
\text { consider external stakeholders. An example of such an approach is the design of new packaging to increase its recyclability with the aim of } \\
\text { changing consumer behavior in the long term. }\end{array}$ \\
\hline Company F & High & $\begin{array}{l}\text { Their long-term perspective allows them to deploy initiatives with long-term impacts. One of their aim is to develop healthier habits among } \\
\text { consumers and to create a new market in the next fifteen years. Thus, a healthy product line has been developed despite its higher cost in the short } \\
\text { term to influence healthier behaviors in the long term and create a new market. }\end{array}$ \\
\hline Company B & High & $\begin{array}{l}\text { Their sustainability plan includes goals over a ten-year period. Internal sustainability can be achieved in the short term, but to actually make a } \\
\text { change in the long term, it is necessary to act at the system level. Owing to their long term perspective, healthier product lines have been } \\
\text { developed as well as environmental initiatives with suppliers to reduce waste along the supply chain. }\end{array}$ \\
\hline Company A & High & $\begin{array}{l}\text { Owing to their long-term planning horizon, a healthy product line has been developed despite its higher cost in the short term to influence } \\
\text { healthier behavior among consumers and become the leader in a new market in the next ten years. }\end{array}$ \\
\hline Company $\mathbf{H}$ & High & $\begin{array}{l}\text { They have a long-term strategy covering the next ten years. If they wanted to achieve sustainability is the short term, they could have aimed to } \\
\text { acquire environmental and social certifications. However, this is not the way to be sustainable in the long term. To do so, it is necessary to act in a } \\
\text { way that considers the impact of business activities on the external community. This is what they consider when taking decisions. For example, an } \\
\text { air filtering and closed-loop system was adopted because of its long-term benefits on employee working conditions and the landscape. }\end{array}$ \\
\hline Company D & High & $\begin{array}{l}\text { They want to be sustainable in the long term, and this cannot be achieved alone. A special long-term agreement with local suppliers has been put } \\
\text { in place because short-term collaborations were expected to damage their survival and long-term economic sustainability. }\end{array}$ \\
\hline Company L & Low & $\begin{array}{l}\text { Their sustainability plan is defined with a horizon of five years. Specific investments are made to make sure that specific short-term goals are } \\
\text { achieved (for example, new production technologies). Social aspects are developed through philanthropic activities but not in connection to the } \\
\text { business, because social aspects and issues related to the business are uncertain and have long-term effects. }\end{array}$ \\
\hline Company E & Low & $\begin{array}{l}\text { They know that some of their competitors are investing in more sustainable product lines, but this is not yet a reality in the market. Thus, given } \\
\text { short-term financial goals, such investments are not considered at the moment. }\end{array}$ \\
\hline Company G & Low & $\begin{array}{l}\text { Their sustainability plan is functional with respect to their annual financial goals. Thus, for example, a water-cleaning filter and a closed-loop } \\
\text { system to reuse water were not installed because of their negative economic impacts in the short term despite the damage to the landscape. }\end{array}$ \\
\hline Company I & Low & $\begin{array}{l}\text { A water-cleaning filter to reuse water was not installed because of its negative economic impacts in the short term despite the high amount of } \\
\text { water used to clean vegetables. }\end{array}$ \\
\hline
\end{tabular}




\subsection{Tolerance of uncertainty and technological change associated with innovations}

The cross-case analysis showed that the analyzed organizations' tolerance of uncertainty related to economic returns differed. Specifically, in four cases, it was higher, and qualitative assessment of the organizations' potential to exploit innovations and of the value of investments was included in the evaluation. In contrast, tolerance of uncertainty was lower in six cases, and only traditional methods (e.g., NPV) were used to evaluate the economic returns of innovations; furthermore, these companies tend to require reliable information and results estimation in their decision making. Specifically, during the interviews, the analyzed organizations mentioned uncertainty when referring to technologically innovative initiatives.

As shown by comparing Table 2 and Table 3, organizations with higher tolerance of uncertainty (i.e., Companies A, B, C and F) adopted technologically innovative initiatives to a greater extent, whereas organizations with lower tolerance of uncertainty adopted technologically innovative initiatives to an average or lower extent.

Table 5 illustrates how tolerance of uncertainty affects the adoption of technologically innovative initiatives. Organizations with higher tolerance of uncertainty invest in technologically innovative initiatives despite these uncertainties because they give more weight to the possible future benefits despite current uncertainties. Such tolerance of uncertainty is related to the potential to make investments as a starting point and as an opportunity to spur further in order to foster sustainability in the future when more information and knowledge are available. For example, the operations manager at Company A provided the following explanation:

"Some years ago, we decided to invest in an air-cleaning filter even though it was very expensive and the returns on such an investment were unclear. We invested in the air-cleaning filter because I had the intuition that it could provide us with new 
opportunities. I started thinking that we had to look for a way to re-use $\mathrm{CO}_{2}$, and finally, we found it. We continuously improved our system to the point that the $\mathrm{CO}_{2}$ recovered can now be reused in carbonated drinks. This would not have been possible without that initial investment.”

Another informant, the carbon master footprint manager at Company F, similarly noted the following:

“A few years ago, we decided to implement a water filter to develop a closed-loop system despite its high costs and uncertain results. Ultimately, the company has saved money by reusing the water, which has provided an even greater benefit in terms of environmental sustainability."

In contrast, organizations characterized by lower tolerance of uncertainty recognized the importance of investing in innovations associated with high technological change to improve their sustainability performance, but given their lower tolerance of uncertainty, these organizations limited their investments in technologically innovative initiatives. For example, as anticipated in section 4.1, Company G decided to not invest in a water-cleaning filter and a closed-loop system because the NPV analysis suggested that the economic results may be negative, and it asked for a dispensation with respect to the investment from the local community. Similar evaluations were performed in Companies L, E and I, and innovations with uncertain economic returns were rejected. 
Table 5: Tolerance of uncertainty and sustainable innovativeness

\begin{tabular}{|c|c|c|}
\hline Organization & $\begin{array}{l}\text { Tolerance of } \\
\text { uncertainty }\end{array}$ & Illustration from the interview data \\
\hline Company C & High & $\begin{array}{l}\text { An energy cogeneration system was put in place despite its high costs and uncertain economic results because they believed in its } \\
\text { potential benefits with respect to the environment and future potential savings. }\end{array}$ \\
\hline Company F & High & $\begin{array}{l}\text { A water filter to develop a closed-loop system was put in place despite its high costs and uncertain economic results because they } \\
\text { did a qualitative evaluation of its potential benefits with respect to creating new opportunities in the future. }\end{array}$ \\
\hline Company B & High & $\begin{array}{l}\text { A water filter to develop a closed-loop system was put in place despite its high costs and uncertain economic results because they } \\
\text { believed in its potential benefits with regard to the environment and future potential savings. }\end{array}$ \\
\hline Company A & High & $\begin{array}{l}\text { An air-cleaning filter was put in place despite its high cost and the unclear return on such an investment because they believed in } \\
\text { the possibility of finding a new way to use it to generate both environmental and social benefits. }\end{array}$ \\
\hline Company $\mathbf{H}$ & Low & $\begin{array}{l}\text { Economic evaluation was used to evaluate projects. Less expensive projects and those with predictable outcomes were preferred } \\
\text { over those that were more expensive and uncertain. }\end{array}$ \\
\hline Company D & Low & $\begin{array}{l}\text { The organization could not afford to invest in uncertain projects, and thus, technological projects with unclear outcomes were } \\
\text { rejected. }\end{array}$ \\
\hline Company L & Low & $\begin{array}{l}\text { Economic evaluation and breakeven analysis were used to evaluate projects. Risky and unclear technological projects were } \\
\text { rejected. }\end{array}$ \\
\hline Company E & Low & $\begin{array}{l}\text { NPV was used to evaluate investments. Thus, technological projects that appeared to be economically uncertain at the moment } \\
\text { were rejected. }\end{array}$ \\
\hline Company G & Low & $\begin{array}{l}\text { NPV was used to evaluate a water-cleaning filter and a closed-loop system to reuse water, but based on the available information, } \\
\text { there were possible negative economic impacts, and the organization asked for a dispensation to postpone the investment. }\end{array}$ \\
\hline Company I & Low & $\begin{array}{l}\text { A water-cleaning filter to reuse water was not installed because of possible negative economic impacts in the short term despite } \\
\text { the high amount of water used to clean vegetables and its impacts on the environment. }\end{array}$ \\
\hline
\end{tabular}




\subsection{Ability to learn from the past and the evolution of sustainable innovativeness}

The cross-case analysis revealed different patterns in the analyzed organizations in relation to the ability to learn from the past. Specifically, four organizations made continuous references to previous knowledge and experience when describing innovations that they adopted, whereas six organizations did not explicitly mention previous experience and knowledge in relation to their adopted innovations.

As shown by comparing Table 2 and 3, these different ways of tackling past experience are related to different paths of evolution of the organizations' degree of sustainable innovativeness: organizations with greater ability to learn from the past are able to achieve a higher and increasing level of sustainable innovativeness, whereas organizations with lower ability to learn from the past are associated with stable or decreasing levels of sustainable innovativeness.

Table 6 illustrates how the ability to learn from the past may influence the evolution of the degree of sustainable innovativeness. Specifically, in organizations with greater ability to learn from the past, innovations are adopted through a continuous learning process, resulting in an increasing level of innovativeness. These organizations described the innovations that they adopted by relating their past experience with the present and the future. In other words, they combine previous knowledge and experience with new knowledge to create structural and radical innovations. Accordingly, in these organizations, sustainable innovations were described during the interviews along an evolutionary path with common goals and increasing levels of effectiveness. For instance, the HSE manager at Company C provided the following explanation:

"We have arrived at this point after a long journey. We have built a level of knowledge over the years step by step. When we started our journey toward sustainability, experts in agronomy were involved to study the most efficient ways to cultivate wheat. We knew that our footprint at the initial stage of our supply chain was not good, and we identified this as a good 
starting point. Thanks to this collaboration, we understood that we needed to engage with our suppliers to improve our footprint, and we started longer collaborative contracts with them to build together something better. Together, we learned how to reduce water consumption, but we always had in mind that something better could be done in the future. For this reason, now we are building a circular supply chain where suppliers cultivating different products are contacted to share cultivation techniques and define the best rotation for crops."

Other informants suggested a similar path to develop healthy production lines. For example, the supply chain and operations manager at Company F noted the following:

"We have been the first ones in our market to introduce a product line dedicated to healthier and more sustainable habits. First, an initiative with the customer service department was put in place to understand consumers' habits. Then, collaboration with a scientific institution dedicated to nutrition studies was established, and information about possible healthy recipes was added to the packaging of our products. Based on these experiences, a new product line was then developed."

In contrast, organizations characterized by lower ability to learn from the past did not continuously improve their innovations and showed stable or decreasing levels of sustainable innovativeness regarding the innovations they adopted. During the interviews, they listed innovations one by one, without describing a common plan or the evolution of their adopted innovations. They did not cite previous experience in relation to their adopted innovations, and each innovation aimed to immediately improve the present situation without a connection to the past or the future. For example, when describing an innovation previously adopted, the operations manager at company $G$ noted as follows: "At that time, we implemented new machineries to reduce worker fatigue because they were suggested during a certification audit to get the certification.”

They described the innovation as something contingent to that situation. Similarly, innovations in the other organizations characterized by lower ability to learn from the 
Table 6: Ability to learn from the past and sustainable innovativeness

\begin{tabular}{|c|c|c|}
\hline Organization & $\begin{array}{l}\text { Ability to learn } \\
\text { from the past }\end{array}$ & Illustration from the interview data \\
\hline Company C & High & $\begin{array}{l}\text { First, experts in agronomy were involved to study the most efficient ways to cultivate grain. As a result, new knowledge was obtained, and the } \\
\text { need for longer collaborative contracts was understood and put in place. Based on the successful experience concerning supplier } \\
\text { collaboration, a circular supply chain where suppliers cultivating different products are contacted to share cultivation techniques and define } \\
\text { the best rotation of lands was established. }\end{array}$ \\
\hline Company F & High & $\begin{array}{l}\text { First, an initiative with the customer service department was put in place to understand consumers' habits. Then, collaboration with a } \\
\text { scientific institution dedicated to nutrition studies was established, and suggestions for healthier habits were added to the product packaging. } \\
\text { Based on that, a new product line was put in place. }\end{array}$ \\
\hline Company B & High & $\begin{array}{l}\text { First, collaboration with a scientific institution dedicated to nutrition studies was established. Then, based on what was learned, changes were } \\
\text { made to the product packaging to suggest healthier diets and lifestyles. Finally, a new product line was put in place. }\end{array}$ \\
\hline Company A & High & $\begin{array}{l}\text { First, a system to share information with business customers to reduce waste and increase production-planning reliability was put in place. } \\
\text { Then, incremental changes were made in the transportation mode to optimize transportation methods. Finally, after the main issues regarding } \\
\text { the customer and transportation sides were understood, owing to previous initiatives, collaboration with business customers and a packaging } \\
\text { producer was established to define a new packaging system in order to reduce food waste during transportation and disposal. }\end{array}$ \\
\hline Company $\mathbf{H}$ & Low & $\begin{array}{l}\text { Innovations were described as single initiatives contingent to the current situation. Past and related experiences were not often mentioned in } \\
\text { relation to adopted innovations. Innovations were described for example in relation to contingent customer requests. }\end{array}$ \\
\hline Company D & Low & $\begin{array}{l}\text { Innovations were described as single initiatives contingent to the current situation. Past and related experiences were not often mentioned in } \\
\text { relation to adopted innovations. Innovations were described for example in relation to contingent customer requests. }\end{array}$ \\
\hline Company L & Low & $\begin{array}{l}\text { Innovations were described as single initiatives contingent to the current situation. Past and related experiences were not often mentioned in } \\
\text { relation to adopted innovations. Innovations were described for example in relation to contingent certification needs. }\end{array}$ \\
\hline Company E & Low & $\begin{array}{l}\text { Innovations were described as single initiatives contingent to the current situation. Past and related experiences were not often mentioned in } \\
\text { relation to adopted innovations. Innovations were described for example in relation to contingent certification needs. }\end{array}$ \\
\hline Company G & Low & $\begin{array}{l}\text { Innovations were described as single initiatives contingent to the current situation. Past and related experiences were not often mentioned in } \\
\text { relation to adopted innovations. Innovations were described for example in relation to contingent certification needs. }\end{array}$ \\
\hline Company I & Low & $\begin{array}{l}\text { Innovations were described as single initiatives contingent to the current situation. Past and related experiences were not often mentioned in } \\
\text { relation to adopted innovations. Innovations were described for example in relation to contingent certification needs and customer requests. }\end{array}$ \\
\hline
\end{tabular}


past have not been defined in a coherent path but as stand-alone initiatives answering contingent needs.

\subsection{Relationship with performance}

The second main objective of the research is to explore the relationship among organizational time perspective, sustainable innovativeness and the improvement of triple bottom line outcomes. As mentioned above, the cross-case analysis allowed us to identify three main groups of organizations that are characterized by different time perspectives and degrees of sustainable innovativeness. As shown in Table 7, these three groups of organizations differ also in relation to their triple bottom line outcomes. Specifically, organizations with a linear time perspective and limited sustainable innovativeness show greater improvement in economic performance than in social and environmental performance. In contrast, organizations with a mixed time perspective and stable sustainable innovativeness show greater improvement in environmental and social performance than the previous group of organizations but worse economic performance. Finally, organizations with a cyclical time perspective and increasing sustainable innovativeness show greater improvement in environmental and social performance than the other two types of organizations, as well as greater improvement in economic performance than organizations with a mixed time perspective and worse improvement in economic performance than organizations with a linear time perspective. However, if an overall index that includes all three dimensions of the triple bottom line is considered, they perform better than the two other types of organizations overall. 
Table 7: Time perspective, sustainable innovativeness and triple bottom line

\begin{tabular}{|c|c|c|c|c|c|c|c|c|}
\hline \multirow[b]{2}{*}{ Organization } & \multirow{2}{*}{$\begin{array}{c}\text { Time } \\
\text { perspective }\end{array}$} & \multirow{2}{*}{$\begin{array}{c}\text { Sustainable } \\
\text { innovativeness }\end{array}$} & \multicolumn{4}{|c|}{ TBL dimensions improvement* } & \multirow{2}{*}{$\begin{array}{l}\text { Overall TBL } \\
\text { improvement }\end{array}$} & \multirow[b]{2}{*}{ Illustration from the interview data } \\
\hline & & & Econ. & Environ. & Int. social & Ext. social & & \\
\hline Company C & Cyclical & $\begin{array}{c}\text { Higher and } \\
\text { increasing }\end{array}$ & $\begin{array}{l}\text { Somewhat } \\
\text { above } \\
\text { average }\end{array}$ & $\begin{array}{l}\text { Somewhat } \\
\text { above } \\
\text { average }\end{array}$ & $\begin{array}{l}\text { Somewhat } \\
\text { above } \\
\text { average }\end{array}$ & $\begin{array}{l}\text { Somewhat } \\
\text { above } \\
\text { average }\end{array}$ & $\begin{array}{c}\text { Somewhat } \\
\text { above average }\end{array}$ & $\begin{array}{l}\text { Environmental and social sustainability are deployed by building resources and } \\
\text { capabilities step by step to avoid reducing finances for the future. }\end{array}$ \\
\hline Company F & Cyclical & $\begin{array}{l}\text { Higher and } \\
\text { increasing }\end{array}$ & Average & $\begin{array}{l}\text { Somewhat } \\
\text { above } \\
\text { average }\end{array}$ & $\begin{array}{l}\text { Somewhat } \\
\text { above } \\
\text { average }\end{array}$ & $\begin{array}{l}\text { Somewhat } \\
\text { above } \\
\text { average }\end{array}$ & $\begin{array}{c}\text { Somewhat } \\
\text { above average }\end{array}$ & $\begin{array}{l}\text { Environmental and social performance can be deployed only sequentially: the } \\
\text { problem must be fixed before it is built upon. This is how environmental and } \\
\text { social performance have been improved and how the investments have been } \\
\text { paid back. }\end{array}$ \\
\hline Company A & Cyclical & $\begin{array}{c}\text { Higher and } \\
\text { increasing }\end{array}$ & $\begin{array}{l}\text { Somewhat } \\
\text { below } \\
\text { average }\end{array}$ & Average & Average & Average & $\begin{array}{c}\text { Somewhat } \\
\text { below average }\end{array}$ & $\begin{array}{l}\text { Environmental and social performance are improved through a sequence of } \\
\text { incremental innovations, followed by radical innovations with good economic } \\
\text { performance. }\end{array}$ \\
\hline Company $\mathrm{H}$ & Mixed & $\begin{array}{l}\text { Average and } \\
\text { stable }\end{array}$ & $\begin{array}{l}\text { Somewhat } \\
\text { above } \\
\text { average }\end{array}$ & $\begin{array}{l}\text { Somewhat } \\
\text { below } \\
\text { average }\end{array}$ & $\begin{array}{l}\text { Somewhat } \\
\text { below } \\
\text { average }\end{array}$ & $\begin{array}{l}\text { Below } \\
\text { average }\end{array}$ & $\begin{array}{c}\text { Somewhat } \\
\text { below average }\end{array}$ & $\begin{array}{l}\text { Environmental and social performance have been improved with a stable set of } \\
\text { initiatives. }\end{array}$ \\
\hline Company $\mathbf{L}$ & Linear & $\begin{array}{l}\text { Lower and } \\
\text { decreasing }\end{array}$ & $\begin{array}{l}\text { Somewhat } \\
\text { above } \\
\text { average }\end{array}$ & $\begin{array}{c}\text { Somewhat } \\
\text { below } \\
\text { average }\end{array}$ & Average & $\begin{array}{l}\text { Somewhat } \\
\text { below } \\
\text { average }\end{array}$ & $\begin{array}{c}\text { Somewhat } \\
\text { below average }\end{array}$ & $\begin{array}{l}\text { Environmental and social compliance is achieved when it fits with the } \\
\text { company's financial goals. Adopted initiatives are in accordance to this } \\
\text { principle. }\end{array}$ \\
\hline Company E & Linear & $\begin{array}{l}\text { Lower and } \\
\text { decreasing }\end{array}$ & $\begin{array}{l}\text { Somewhat } \\
\text { below } \\
\text { average }\end{array}$ & Average & Average & Average & $\begin{array}{c}\text { Somewhat } \\
\text { below average }\end{array}$ & $\begin{array}{l}\text { Environmental and social performance are sufficient because investments are } \\
\text { limited and financial goals are met. }\end{array}$ \\
\hline Company G & Linear & $\begin{array}{l}\text { Lower and } \\
\text { decreasing }\end{array}$ & Average & $\begin{array}{c}\text { Somewhat } \\
\text { below } \\
\text { average }\end{array}$ & $\begin{array}{c}\text { Somewhat } \\
\text { below } \\
\text { average }\end{array}$ & $\begin{array}{l}\text { Below } \\
\text { average }\end{array}$ & $\begin{array}{c}\text { Somewhat } \\
\text { below average }\end{array}$ & $\begin{array}{l}\text { Environmental and social compliance have been achieved with limited short- } \\
\text { term investments in order to contribute to financial performance. }\end{array}$ \\
\hline Company I & Linear & $\begin{array}{l}\text { Lower and } \\
\text { decreasing }\end{array}$ & Average & $\begin{array}{c}\text { Somewhat } \\
\text { below } \\
\text { average }\end{array}$ & $\begin{array}{c}\text { Somewhat } \\
\text { below } \\
\text { average }\end{array}$ & $\begin{array}{c}\text { Below } \\
\text { average }\end{array}$ & $\begin{array}{c}\text { Somewhat } \\
\text { below average }\end{array}$ & $\begin{array}{l}\text { Environmental and social performance are achieved in line with compliance } \\
\text { and with limited financial investments. }\end{array}$ \\
\hline
\end{tabular}

* Specific measures and assessment of the triple bottom line dimensions are provided in Appendix C. 
Table 7 also provides further illustrations from the interview data about how different time perspectives and different degrees of sustainable innovativeness may have affected the improvement of triple bottom line outcomes. Specifically, in organizations with a cyclical time perspective and a higher and increasing level of sustainable innovativeness, the ability to combine a longer planning horizon, higher tolerance of uncertainty and greater ability to learn from the past allowed them to adopt sustainable innovations in a sequence of increasingly innovative initiatives that enabled them to achieve greater improvements in environmental and social performance and mitigate possible negative impacts on economic performance. For instance, the operations manager at Company B provided the following statement:

“Our long-term sustainability plan has been deployed considering the best way to improve environmental and social performance in the long term. This could be done only with great innovations. However, these innovations are risky investments and may lock you in. Thus, at the beginning, we started innovating considering how to fix our environmental and social performance with incremental changes in our systems and processes and without compromising our financial performance to the point that we couldn't perform well in the long term. Then, by learning from each initiative adopted, we increasingly changed our systems to get better sustainability outcomes. This allowed us to improve our environmental and social performance but keep our finances safe.”

In contrast, organizations with a mixed time perspective and average and stable sustainable innovativeness had long-term sustainability plans but did not connect the past, present and future and had low tolerance of uncertainty; thus, they adopted a stable set of sustainable innovations that had positive but limited effects -compared to organizations with a cyclical time perspective and greater innovativeness-on their environmental and 
social performance with that required continuous investments. For instance, the Environmental development manager at Company H provided the following explanation:

"In this year, we have been investing in the same set of sustainable initiatives that we believe could benefit our stakeholders and supply chain partners.... Years ago, we decided it was the right way to do it, and we keep on doing it, even though it requires money, time and resources."

Finally, organizations with a linear time perspective and low and decreasing sustainable innovativeness showed greater economic improvement but lower environmental and social improvement. Accordingly, their linear time perspective and lower level of innovativeness limited their investments related to sustainable innovations, allowing them to invest more in other business-related activities but simultaneously limiting environmental and social improvements. The operations manager at Company G noted as follows:

“Our sustainability plan is contingent on our financial goals and business plan. Sustainability has to pay off in the fiscal year. If initiatives don't fit with this rule, we don't adopt them. We are focused on increasing our business now, and sustainability initiatives that are adopted should not reduce resources available for other investments and should be consistent with current issues. In doing so, we are able to be environmentally and socially compliant without negatively affecting our bottom line.”

\section{Discussion and research propositions}

In this research, we examined how an organization's time perspective influences its degree of sustainable innovativeness and improvement of the triple bottom line. Although previous literature has examined the role of organizational time perspective in relation to environmental and social issues (e.g., Slawinski and Bansal, 2012; Das, 2005), previous 
studies have rarely considered either multiple dimensions of the triple bottom line simultaneously or the degree of innovativeness of the initiatives implemented. However, an increasing number of researchers are calling for studies on an integrated view of sustainability that aims to improve multiple dimensions of the triple bottom line jointly (Gao and Bansal, 2013; Hahn et al., 2014) and to inform relevant changes in technologies and business models that such an approach may require (Pinkse and Kolk, 2010; Hahn et al., 2015).

We used a multiple case study approach to fill these research gaps. We found that organizations with different time perspectives show different degrees of sustainable innovativeness and different levels of improvement of triple bottom line outcomes. Extending previous findings from Slawinski and Bansal (2012), our results show that three aspects in particular contribute to the existence of diverse time perspectives in approaching the deployment of sustainable innovativeness and triple bottom line outcomes.

The first aspect that contributes to sustainable innovativeness is a longer planning horizon. Specifically, this aspect contributes to the adoption of innovations that have effects at both the organizational and societal level (i.e., societally innovative initiatives), thus crossing organizations' borders. Previous literature suggests that innovations that have an impact at both the organizational and societal levels positively affect the environment and external community, preserve the landscape, and consequently improve the organization's image, which increases workers' goodwill, attracts better workers, and improves the organization's long-term economic performance (Greening and Turban, 2000; Turban and Greening, 1997; Pagell and Gobeli, 2009). The interviews highlighted that organizations with a longer planning horizon understand that sustainability is a long term goal that can be sustained only through consideration of organizational impacts at 
both the organizational and societal levels. Accordingly, we put forth the following research proposition:

P1. A longer planning horizon fosters the adoption of sustainable innovations with an impact at both the organizational and societal levels.

The second aspect that contributes to sustainable innovativeness is tolerance of uncertainty. Specifically, this aspect contributes to the development of sustainable innovations that provide structural changes in the operations and supply chain systems. Previous literature contributions highlight that the triple bottom line is a multidimensional concept, yet despite the importance of environmental and social aspects, organizations often focus on economic criteria when making decisions (Wu and Pagell, 2011). Moreover, organizations may have to make decisions without complete information about the possible impact of innovations on their economic performance (Wu and Pagell, 2011; Pinkse and Kolk, 2010). Therefore, organizations cannot completely assess the economic results of such innovations. This seems to discourage organizations from adopting sustainable innovations, particularly innovations characterized by a high degree of technological change (Pinkse and Kolk, 2010). This tendency is evident in organizations with lower tolerance of uncertainty, as they evaluate the adoption of sustainable innovations based on NPV analysis and often reject them despite their impact on environmental and social aspects owing to the uncertain economic results.

In contrast, organizations with higher tolerance of uncertainty not only use NPV techniques, which discount future benefits, but also consider potential opportunities and opportunity costs in a qualitative way. Specifically, they consider investments in sustainable innovations as a form of investment that creates opportunities to expand and grow in the future (Bush and Hoffman, 2009). They accept current uncertainties in the 
results that could be obtained and decide to make investments that may open new options in the future when more information and knowledge will be available to leverage on them. In addition, they value environmental and social performance and place less emphasis on economic results. Therefore, we suggest the following proposition:

P2. Higher tolerance of uncertainty supports the adoption of sustainable innovations with a high degree of technological change.

The third aspect that contributes to sustainable innovativeness is the ability to learn from the past. Organizations characterized by greater ability to learn from the past adopt increasingly innovative initiatives and radical innovations to a greater extent. Such innovations have often been built on previously adopted innovations through a path of continuous learning. The innovation literature suggests that more innovative and radical innovations are the result of repeated cycles of divergent and convergent phases and that they evolve not from a linear process but from the accumulation of knowledge and various attempts at improvement (Garud et al., 2013). We contribute to this literature by suggesting that organizations with greater ability to learn from the past through a doubleloop learning approach are able to exploit interconnections between innovations in order to build a continuous improvement path. In contrast, organizations lacking the ability to learn from the past adopt a relatively stable mix of sustainable innovations over time and invest in increasingly innovative and radical innovations to a limited extent. Accordingly, we put forth the following proposition:

P3. The ability to learn from the past supports a continuous innovation cycle to develop increasing sustainable innovativeness.

A main challenge related to improvement of the triple bottom line is the presence 
in many cases of trade-offs between economic performance and environmental and social performance (e.g., Hahn et al., 2015; Gao and Bansal, 2013). Accordingly, our results show that organizations with cyclical and mixed time perspectives and higher degrees of innovativeness show greater improvement in environmental and social performance and average or below average improvement in economic performance in comparison with organizations with a linear time perspective and lower innovativeness. Organizations with a cyclical time perspective take the opportunity to invest in innovations and to then build on their accumulated knowledge in order to evaluate innovations and further develop them in the future. Taking a real option perspective, these organizations are more willing to make currently uncertain investments (owing to their higher tolerance of uncertainty), to aim to improve their potential benefits in the long term (owing to their longer planning horizon), and to build on their previous knowledge and experience (owing to their greater ability to learn from the past). The investment in innovation is perceived as an option to grow or expand. In other words, they perceive opportunity costs of waiting related to the fact that waiting may mean that they delay the possible positive impacts on their triple bottom line performance and lose the opportunity to create continuous knowledge and innovation. They consider sustainable innovations to be opportunities that, if not taken, may reduce their possibility to improve the triple bottom line. However, this may also imply higher structural costs in current investments, as current resources must be employed in such activities, and may also engender lock-in effects and high switching costs.

In contrast, organizations with a linear time perspective are concerned with finding efficient and immediate solutions to sustainability. Their time perspective dissuades them from adopting major innovations with long-term and uncertain impacts (owing to their shorter planning horizon and lower tolerance of uncertainty), and they decide to avoid or 
postpone them and focus on the present (owing to their lower ability to learn from the past). Having a linear time perspective, they do not perceive any opportunity costs of waiting (Cassimon et al., 2015); thus, they delay sustainability investments and achieve better economic performance despite achieving worse environmental and social performance.

Figure 2 represents these three groups of organizations that differ in relation to their time perspective, sustainable innovativeness and triple bottom line improvements. The figure shows that there is a trade-off relationship between economic performance and environmental and social performance. In any case, the group of organizations characterized by a cyclical time perspective and increasing higher innovativeness is associated with better overall improvement when triple bottom line outcomes are considered jointly.

Figure 2: Organizations' triple bottom line achievements about here

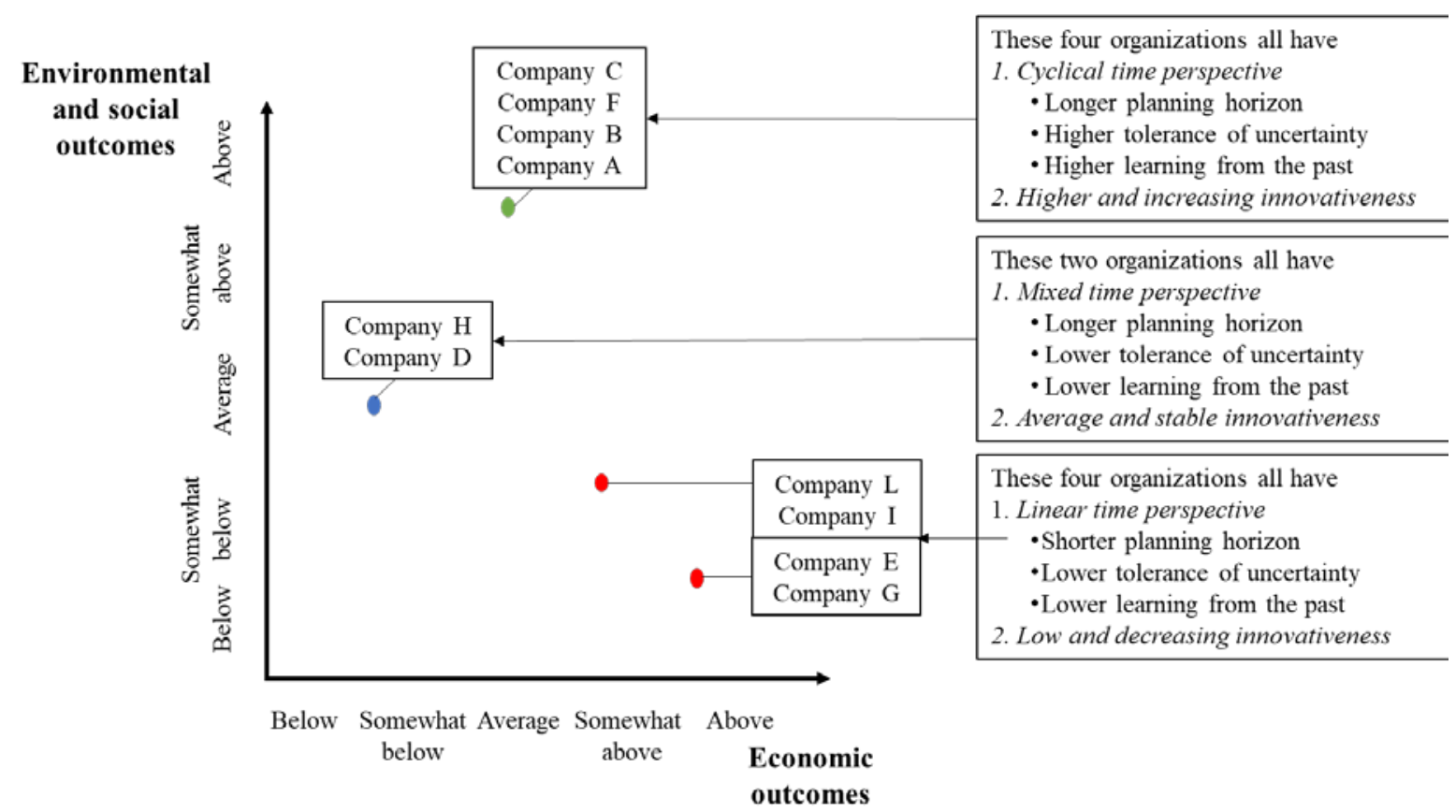

Thus, our study shows that although trade-offs between economic outcomes and environmental and social outcomes may exist; the trade-off frontier can be advanced 
through a cyclical time perspective and sustainable innovativeness. Previous literature suggests that the trade-off frontier is a dynamic, living curve whose exact shape and location may differ according to the learning and innovation capabilities of an organization (Lankoski, 2008). We build on this literature and suggest that organizations with a cyclical time perspective can advance the efficiency frontier of the triple bottom line (i.e., better overall improvement of the triple bottom line) by developing a continuous innovation path that ultimately leads to sustainable radical innovation. Technological breakthroughs can, for example, dramatically reduce the costs of environmental and social innovations, thus mitigating negative impacts on economic performance. Accordingly, organizations with a cyclical time perspective show fewer trade-offs with respect to their economic, environmental, and social performance than organizations with a mixed time perspective, or they at least mitigate such trade-offs and optimize improvements in different triple bottom line dimensions to a greater extent than other organizations. Therefore, we suggest the following proposition:

P4. A longer planning horizon, higher tolerance of uncertainty and greater ability to learn from the past, associated with increasing sustainable innovativeness, improve an organization's environmental and social performance while mitigating trade-offs between economic performance and environmental and social performance.

\section{Conclusion}

This research answers the calls to study business ethics and sustainability in relation to social, environmental, and economic aspects (Hahn et al., 2015; Gao and Bansal, 2013). Specifically, we contribute to this debate by describing the role of an organization's time perspective in its degree of sustainable innovativeness that improves the organization's triple bottom line. 
We show that an organization's time perspective plays a key role in the adoption of sustainable innovations characterized by different degrees of innovativeness. Rather than simply considering short- and long-term horizons, we consider a more complex view of organizations’ time perspective. In particular, building on previous research by Slawinski and Bansal (2012), we also study organizations' time perspective in relation to their tolerance of uncertainty and ability to learn from the past. We show that these aspects of organizations' time perspective are important for understanding the degree of innovativeness associated with organizations' adopted sustainable innovations. Furthermore, this research provides empirical evidence of the role of organizations' time perspective in fostering a holistic view of an organization's ethical and its moral responsibilities related to environmental and social performance and advancing the efficiency frontier with regard to the triple bottom line. Thanks to a cyclical time perspective organizations can enact the necessary responsibility of organizations to develop sustainable innovations contributing to the future of societies and the natural environment. If such time perspective is missing, then organizations will face challenges and barriers to develop sustainable innovations, enacting a holistic business ethics view, and will focus on traditional business-oriented practices.

\subsection{Implications for practice}

Our research informs practitioners that the development of a holistic view of business ethics comprising social, environmental, and economic needs of future generations and the triple bottom line approach is complex and requires a different time perspective than traditional management models. In particular, a longer planning horizon together with higher tolerance of uncertainty and a greater ability to learn from the past may lead to increasing sustainable innovativeness that provides environmental and social 
improvements and mitigates possible negative impacts on organizations' economic performance. Such a time perspective enables organizations to think holistically in relation to their social, environmental, and economic responsibilities and stakeholders and to foster innovation processes in order to optimize both their environmental and social performance and any economic trade-offs. In contrast, a limited time horizon, a lack of tolerance of uncertainty and a limited ability to learn from the past may lead to sustainable innovations associated with a limited degree of sustainable innovativeness. Such time perspective is mainly oriented to traditional business goals rather than business ethics concerns concerning the future of societies and the natural environment. Consequently, organizations adopting such a perspective may experience greater improvement in their economic performance but may achieve limited improvement in their environmental and social performance.

\subsection{Limitations and future research}

Despite its important theoretical and practical contributions, this research suffers from some methodological limitations. First, most empirical research - including many qualitative and quantitative studies - is backward looking by nature (Pagell and Shevchenko, 2014). We examined the path to the development of the triple bottom line in ten organizations; however, we are unable to foresee future trends and results. Our study nevertheless shows a longitudinal trend in the adoption and effects of sustainable innovations.

Second, although we attempted to conduct a longitudinal study, our research design might lead to biased results because organizational narratives or myths about past events can alter the information provided during interviews. We tried to overcome such bias by triangulating the data from the interviews with analysis of annual and sustainability 
reports. However, repeated interviews and observations along different points in time could have benefited our research.

Third, our sample is limited; thus, future research might test our propositions on a wider number of organizations in different industries and countries to test the generalizability of our results.

Furthermore, the indicators of triple bottom line outcomes are still being developed, particularly with respect to the social sustainability dimension. In our research, we decided to focus on the most objective performance indicators suggested by the GRI guidelines. However, the indicators that we used represent only a limited sub-set and may not capture the overall complexity of the triple bottom line dimensions. Future research testing our propositions may benefit from advancements in the sustainability accountability literature and include other performance indicators in the analysis.

Finally, the current study does not explicitly consider the role of stakeholders in the adoption of sustainable innovations. However, sustainable innovations may be adopted to legitimate the organization in the eyes of its stakeholders (e.g., stakeholder management) and through engagement with them (e.g., stakeholder accountability). Thus, we suggest that a possible research direction may be to study the link between sustainable innovativeness and both stakeholder management and accountability. 


\section{Appendix A}

Table A.1: Data sources

\begin{tabular}{|c|c|c|c|}
\hline Organization & Interviews & Secondary data sources & Observations \\
\hline Company A & $\begin{array}{l}\text { - HSE director } \\
\text { - Operations manager } \\
\text { - Internal communication and } \\
\text { HRM manager } \\
\text { - Public affairs and public } \\
\text { relations manager } \\
\text { - Brand manager }\end{array}$ & $\begin{array}{l}\text { - Various documents about the history of } \\
\text { the organization } \\
\text { - Financial report } \\
\text { - Sustainability report } \\
\text { - Organizational website } \\
\text { - Internal documents about environmental } \\
\text { management and policy } \\
\text { - Internal document about the next year's } \\
\text { goals } \\
\text { - Results of a Green Forum meeting }\end{array}$ & $\begin{array}{l}\text { - Italian } \\
\text { headquarters } \\
\text { - Plant }\end{array}$ \\
\hline Company B & $\begin{array}{l}\text { - Internal communication and } \\
\text { HRM manager } \\
\text { - Talent recruiting manager } \\
\text { - Operations manager } \\
\text { - Business development } \\
\text { manager }\end{array}$ & $\begin{array}{l}\text { - Various documents about the history of } \\
\text { the organization } \\
\text { - Financial report } \\
\text { - Sustainability report } \\
\text { - Organizational website } \\
\text { - Internal documents about environmental } \\
\text { and social management and policy }\end{array}$ & $\begin{array}{l}\text { - Italian } \\
\text { headquarters } \\
\text { - Plant }\end{array}$ \\
\hline Company C & $\begin{array}{l}\text { - Human capital manager } \\
\text { - HSE manager } \\
\text { - Operations manager }\end{array}$ & $\begin{array}{l}\text { - Various documents about the history of } \\
\text { the organization } \\
\text { - Financial report } \\
\text { - Sustainability report } \\
\text { - Organizational website } \\
\text { - Internal documents about environmental } \\
\text { and social management and policy } \\
\text { - Internal document about the next year's } \\
\text { goals }\end{array}$ & $\begin{array}{l}\text { - Italian } \\
\text { headquarters } \\
\text { - Plant }\end{array}$ \\
\hline Company D & $\begin{array}{l}\text { - SA } 8000 \text { coordinator } \\
\text { - HRM manager } \\
\text { - Operations manager }\end{array}$ & $\begin{array}{l}\text { - Various documents about the history of } \\
\text { the organization } \\
\text { - Financial report } \\
\text { - Sustainability report } \\
\text { - Organizational website } \\
\text { - Internal documents about environmental } \\
\text { and social management and policy }\end{array}$ & $\begin{array}{l}\text { - Headquarters } \\
\text { - Plant }\end{array}$ \\
\hline Company E & $\begin{array}{l}\text {-Internal communication and } \\
\text { HRM manager } \\
\text { - Operations manager } \\
\text { - CSR manager }\end{array}$ & $\begin{array}{l}\text { - Various documents about the history of } \\
\text { the organization } \\
\text { - Financial report } \\
\text { - Sustainability report } \\
\text { - Organizational website } \\
\text { - Internal documents about environmental } \\
\text { and social management and policy }\end{array}$ & $\begin{array}{l}\text { - Headquarters } \\
\text { - Plant }\end{array}$ \\
\hline Company F & $\begin{array}{l}\text { - HRM, skills development, } \\
\text { and internal communication } \\
\text { manager } \\
\text { - EHS manager } \\
\text { - Carbon master footprint } \\
\text { manager } \\
\text { - Supply chain and operations } \\
\text { manager } \\
\text { - Public relations manager } \\
\end{array}$ & $\begin{array}{l}\text { - Various documents about the history of } \\
\text { the organization } \\
\text { - Financial report } \\
\text { - Sustainability report } \\
\text { - Organizational website } \\
\text { - Internal documents about environmental } \\
\text { and social management and policy } \\
\text { - Corporate code of conduct }\end{array}$ & $\begin{array}{l}\text { - Headquarters } \\
\text { - Plant }\end{array}$ \\
\hline Company G & $\begin{array}{l}\text { - Technical director } \\
\text { - Certifications coordinator } \\
\text { - HRM manager } \\
\text { - Operations manager }\end{array}$ & $\begin{array}{l}\text { - Various documents about the history of } \\
\text { the organization } \\
\text { - Financial report } \\
\text { - Sustainability report } \\
\text { - Organizational website } \\
\text { - Internal documents about environmental } \\
\text { and social management and policy } \\
\text { - Internal document about the next year's } \\
\text { goals }\end{array}$ & $\begin{array}{l}\text { - Headquarters } \\
\text { - Plant }\end{array}$ \\
\hline
\end{tabular}




\begin{tabular}{|c|c|c|c|}
\hline Organization & Interviews & Documents & Observations \\
\hline Company $\mathbf{H}$ & $\begin{array}{l}\text { - External and internal } \\
\text { communication, HRM } \\
\text { manager } \\
\text { - Environmental development } \\
\text { manager } \\
\text { - Operations manager }\end{array}$ & $\begin{array}{l}\text { - Various documents about the history of } \\
\text { the organization } \\
\text { - Financial report } \\
\text { - Sustainability report } \\
\text { - Organizational website } \\
\text { - Corporate code of conduct }\end{array}$ & - Headquarters \\
\hline Company I & $\begin{array}{l}\text { - Operations and supply chain } \\
\text { manager } \\
\text { - HRM manager } \\
\text { - Marketing manager }\end{array}$ & $\begin{array}{l}\text { - Various documents about the history of } \\
\text { the organization } \\
\text { - Financial report } \\
\text { - Sustainability report } \\
\text { - Organizational website } \\
\text { - Internal documents about environmental } \\
\text { and social management and policy } \\
\text {-Internal document about the next year's } \\
\text { goals }\end{array}$ & $\begin{array}{l}\text { - Italian } \\
\text { headquarters } \\
\text { - Plant }\end{array}$ \\
\hline Company L & $\begin{array}{l}\text { - External relations and CSR } \\
\text { manager } \\
\text { - HRM manager } \\
\text { - Operations manager }\end{array}$ & $\begin{array}{l}\text { - Various documents about the history of } \\
\text { the organization } \\
\text { - Financial report } \\
\text { - Sustainability report } \\
\text { - Organizational website } \\
\text { - Handbook of corporate principles }\end{array}$ & $\begin{array}{l}\text { - Headquarters } \\
\text { - Plant }\end{array}$ \\
\hline
\end{tabular}




\section{Appendix B}

Table B.1: Semistructured questionnaire

Checklist

\section{Introduction}

1. What is your role in the organization?

2. Where is your department located on the organizational chart?

\section{Focus on the Triple Bottom Line}

3. Is there a CSR department? Where is it located on the organizational chart?

4. Is there a formal or informal structure to manage the definition and implementation of initiatives aimed at the triple bottom line (e.g., team, committee, specific roles)?

5. What does the triple bottom line mean in your organization?

6. Who is committed to the development of the triple bottom line? Who defines goals relate to the triple bottom line?

7. How is commitment to the triple bottom line shared within the organization?

8. Is the triple bottom line pursued by means of certifications, or do you redefine the organization's mission, product, management methods, organizational structure, etc.?

9. What plant- and people-related initiatives are in place?

10. What are the main impacts of those initiatives? Are there any tradeoffs? Are there any synergies?

11. What is needed to make initiatives more effective (e.g., new culture, communications, training)?

\section{Focus on Operations and Supply Chain}

12. How is the operations and supply chain department organized?

13. How is this plant organized? Is the work strictly procedural, or are workers autonomous? Are workers multifunctional and flexible?

14. What are the main aspects of the triple bottom line that are affected by operations and the supply chain?

15. What initiatives are adopted at the plant and supply chain level (e.g., energy and water consumption reduction programs, health and safety programs, pollution control programs)?

\section{Focus on Initiatives/Innovations}

16. Is the definition of initiatives/innovations guided by the organizational culture, the worker culture, external requirements, or regulations?

17. How do you assure coherence among the initiatives/innovations identified? Do HRM and organizational practices have an impact?

18. How do you select initiatives/innovations to be implemented? How do you evaluate their performance impacts?

19. When initiatives/initiatives are implemented, how is the change managed? Are organizational practices (e.g., training, worker involvement) adopted to implement such initiatives?

20. How and to what extent are communication and training practices adopted?

21. Are there any differences in the implementation of initiatives/innovations related to one or more sustainability aspects?

Focus on a Single Initiative/Innovation

22. Can you provide an example of a successful initiative/innovation - can you define it? Can you describe the definition and implementation phases?

23. Can you provide an example of an unsuccessful initiative/innovation - can you define it? Can you describe the definition and implementation phases? 


\section{Appendix C}

Table C.1: Operationalization of the triple bottom line

\begin{tabular}{|c|c|c|}
\hline CONSTRUCTS & $\begin{array}{l}\text { Description and data } \\
\text { source }\end{array}$ & ASSESSMENT \\
\hline $\begin{array}{l}\text { Economic } \\
\text { performance }\end{array}$ & $\begin{array}{ll}- & \text { (EBITDA 2013) } \\
\text { /(sales 2013)- } \\
\text { (EBITDA 2005)- } \\
\quad \text { (sales 2005) } \\
\text { Source: AIDA database } \\
\text { on financial } \\
\text { performance }\end{array}$ & $\begin{array}{l}\text { - Above average (5): the performance metric was } 1 \text { or more standard deviations } \\
\text { above the sample average; } \\
\text { - Somewhat above average (4): the performance metric was half a standard } \\
\text { deviation above the sample average; } \\
\text { - Average (3): the performance metric was the sample average; } \\
\text { Somewhat below average (2): the performance metric was half a standard } \\
\text { - Beviation below the sample average; } \\
\text { Below average (1): the performance metric was } 1 \text { or more standard deviations } \\
\text { below the sample average. }\end{array}$ \\
\hline $\begin{array}{l}\text { Environmental } \\
\text { performance }\end{array}$ & $\begin{array}{l}\text { - \% energy usage } \\
\text { reduction from } 2005 \\
\text { to 2013; } \\
\text { - \% water usage from } \\
2005 \text { to 2013; } \\
\text { - \% } \mathrm{CO}_{2} \text { emission from } \\
2005 \text { to 2013; } \\
\text { - \% raw material usage } \\
\text { reduction from } 2005 \\
\text { to 2013. } \\
\text { Source: Annual } \\
\text { sustainability reports }\end{array}$ & $\begin{array}{l}\text { Average of the performance metric after rescaling each as: } \\
\text { - Above average (5): the performance metric was } 1 \text { or more standard deviations } \\
\text { above the sample average; } \\
\text { - Somewhat above average (4): the performance metric was half a standard } \\
\text { deviation above the sample average; } \\
\text { - Average (3): the performance metric was the sample average; } \\
\text { Somewhat below average (2): the performance metric was half a standard } \\
\text { - } \begin{array}{l}\text { deviation below the sample average; } \\
\text { below average (1): the performance metric was } 1 \text { or more standard deviations }\end{array}\end{array}$ \\
\hline \multirow[t]{2}{*}{$\begin{array}{l}\text { Social } \\
\text { performance: } \\
\text { average of } \\
\text { internal and } \\
\text { external social } \\
\text { performance }\end{array}$} & $\begin{array}{l}\text { - Internal social } \\
\text { performance: \% of } \\
\text { accident reduction } \\
\text { from } 2005 \text { to } 2013 \\
\text { Source: Annual } \\
\text { sustainability reports }\end{array}$ & $\begin{array}{l}\text { - Above average (5): the performance metric was } 1 \text { or more standard deviations } \\
\text { above the sample average; } \\
\text { - Somewhat above average (4): the performance metric was half a standard } \\
\text { deviation above the sample average; } \\
\text { - Average (3): the performance metric was the sample average; } \\
\text { - } \text { Somewhat below average (2): the performance metric was half a standard } \\
\text { deviation below the sample average; } \\
\text { Below average (1): the performance metric was } 1 \text { or more standard deviations } \\
\text { below the sample average. }\end{array}$ \\
\hline & $\begin{array}{l}\text { - External social } \\
\text { performance: \% of } \\
\text { sales of products } \\
\text { improving health and } \\
\text { sustainable life styles } \\
\text { (in-kind } \\
\text { contributions, } \\
\text { volunteer initiatives, } \\
\text { knowledge transfer, } \\
\text { partnerships and } \\
\text { product development) } \\
\text { from } 2005 \text { to 2013. } \\
\text { Source: Annual } \\
\text { sustainability and } \\
\text { financial reports. }\end{array}$ & $\begin{array}{l}\text { - Above average (5): the performance metric was } 1 \text { or more standard deviations } \\
\text { above the sample average; } \\
\text { - Somewhat above average (4): the performance metric was half a standard } \\
\text { deviation above the sample average; } \\
\text { - Average (3): the performance metric was the sample average; } \\
\text { - Somewhat below average (2): the performance metric was half a standard } \\
\text { deviation below the sample average; } \\
\text { Below average (1): the performance metric was } 1 \text { or more standard deviations } \\
\text { below the sample average. }\end{array}$ \\
\hline $\begin{array}{l}\text { Triple bottom } \\
\text { line }\end{array}$ & \multicolumn{2}{|c|}{ Average of environmental, social and economic performance } \\
\hline
\end{tabular}




\section{References}

Adam, B. (1994). Time and social theory. Cambridge, UK: Polity Press.

Aiking, H. and Boer, J. (2004). Food sustainability: Diverging interpretations. British Food Journal. 106 (5), 359-365.

Alas, R. (2006). Ethics in countries with different cultural Dimensions. Journal of Business Ethics. 69, 237-247

Argiris, C. and Schon, D. (1983). Reasoning, learning, and action. Jossey-Bass, San Francisco.

Ashkanasy, N., Gupta, V. and Mayfield, M. S. (2004). 'Future Orientation', in R. House et al. (eds.), Culture, leadership, and organizations (The GLOBE Study of 62 Societies, Sage Publications, Inc.), 282-342

Becker, U.C. (2012). Sustainability ethics and sustainability research. Springer, Heidelberg.

Berrone, P., Fosfuri, A., Gelabert, L. and Gomez-Mejia, L.R. (2013). Necessity as the mother of 'green' inventions: institutional pressures and environmental innovations. Strategic Management Journal. 34(8), 891-909.

Bettley, A. and Burnley, S. (2008). Towards sustainable operations management integrating sustainability management into operations management strategies and practices. In: Misra, Krishna B. ed., Handbook on Performability Engineering, London, UK: Springer-Verlag, 875-904.

Bluedorn, A.C. and Waller, M.J. (2006). The stewardship of the temporal commons. Research in Organizational Behavior. 27, 355-396

Boons, F. and Lüdeke-Freund, F. (2013). Business models for sustainable innovation: state-of-the-art and steps towards a research agenda. Journal of Cleaner Production 45, 9-19.

Booz, E., Allen, J. and Hamilton, C. (1982). New Product Development for the 1980s. Booz Allen \& Hamilton Consultants, New York, NY.

Brammer, S. and Millington, A. (2008). Does it pay to be different? An analysis of the relationship between corporate social and financial performance. Strategic Management Journal. 29, 1325-1343.

Broome, J. (1994). Discounting the future. Philosophy \& Public Affairs. 23(2), 128-156,

Brown, J. and Fraser, M. (2006). Approaches and perspectives in social and environmental accounting: An overview of the conceptual landscape. Business 
Strategy and the Environment. 15(2), 103-117.

Busch, T. and Hoffmann, V. H. (2009). Ecology-driven real options: An investment framework for incorporating uncertainties in the context of the natural environment. Journal of Business Ethics. 90, 295-310.

Campbell, J. L. (2007). Why would corporations behave in socially responsible ways? An institutional theory of corporate social responsibility. Academy of Management Review. 32(3), 946-967.

Cassimon, D., Engelen, P. and Van Liedekerke, L. (2015). When do firms invest in corporate social responsibility? A real option framework. Journal of Business Ethics.

Chen, H., Zeng, S., Lin, H. and Ma, H. (2015). Munificence, dynamism, and complexity: How industry context drives corporate sustainability. Business Strategy and the Environment.

Christmann, P. (2000). Effects of "best practices" of environmental management on cost advantage: The role of complementary assets. Academy of Management Journal. 43 (4), 663-680.

Corbin, J. and Strauss, A. (2008). Basics of qualitative research (3rd ed.). Los Angeles, CA: Sage.

Cornelius, P., Van De Putte, A. and Romani, M. (2005). Three decades of scenario planning in Shell', California Management Review. 48(1), 92-109.

Das, T.K. (2005). How strong are the ethical preferences of senior business executives? Journal of Business Ethics. 56 (1), 69-80

Eisenhardt, K.M. (1989). Building theories from case study research. Academy of Management Review, 14 (4), pp. 532-550.

Elkington, J. (1994). Towards the sustainable corporation: Win-win-win business strategies for sustainable development. California Management Review. 36 (2), 90100.

Elkington, J. (2002). Corporate strategy in the chrysalis economy. Corporate Environmental Strategy. 9(1), 5-12

Florea, L., Cheung, Y. H., and Herndon, N. C. (2013). For all good reasons: Role of values in organizational sustainability. Journal of Business Ethics. 114 (3), 393-408.

Freeman, R.E. (1984). Strategic management: A stakeholder approach. Cambridge, UK: Cambridge University Press.

Fritzsche, D. (1991). A model of decision-making incorporating ethical values. Journal 
of Business Ethics. 10, 841-852

Gallagher, K.S., Holdren, J.P., Sagar, A. D. (2006). Energy-technology innovation. Annual Review of Environment and Resources. 31, 193-237.

Gao, J. and Bansal, P. (2013). Instrumental and integrative logics in business sustainability. Journal of Business Ethics. 112(2), 241-255.

Garcia, R. and Carltone, R. (2002). A critical look at technological innovations typology and innovativeness terminology: a literature review. Journal of Product Innovation Management. 19, 110-132.

Garud, R., Tuertscher, P. and Van de Ven, A. (2013). Perspectives on innovation processes. The Academy of Management Annals. 7(1), 775-819

Gimenez, C., Sierra, V. and Rodon, J. (2012). Sustainable operations: Their impact on the triple bottom line. International Journal of Production Economics. 140(1), 149159.

Gioia, D. A., Corley, K. G. and Hamilton, A. L. (2013). Seeking qualitative rigor in inductive research: Notes on the Gioia methodology. Organizational Research Methods. 16, 15-31.

Greening, D. W. and Turban, D. B. (2000). Corporate social performance as a competitive advantage in attracting a quality workforce. Business and Society. 39(3), 254-280.

Hahn, T., Figge, F., Pinkse, J. and Preuss, L. (2010). Trade-offs in corporate sustainability: You can’t have your cake and eat it. Business Strategy and the Environment. 19(4), 217-229.

Hahn, T., Pinkse, J., Preuss, L. and Figge, F. (2015). Tensions in corporate sustainability: Towards an integrative framework. Journal of Business Ethics. 127, 297-316.

Hahn, T., Preuss, L., Pinkse, J. and Figge, F. (2014). Cognitive frames in corporate sustainability: managerial sensemaking with paradoxical and business case frame. Academy of Management Review. 39 (4), 463-487.

Hallstedt, S., Ny, H., Robert, K.H., Broma, G. (2010). An approach to assessing sustainability integration in strategic decision systems for product development. Journal of Cleaner Production. 18, 703-712.

Held, M. (2001). Sustainable development from a temporal perspective. Time \& Society. 10(2-3), 351-366.

Hellström, T. (2007). Dimensions of environmentally sustainable innovation: The structure of eco-innovation concepts, Sustainable Development. 15, 148-159. 
Ho, F. N., Wang, H. D. and Vitell, S. J. (2012). A global analysis of corporate social performance: The effects of cultural and geographic environments. Journal of Business Ethics. 107, 423-433.

Holahan, P. J., Sullivan, Z. Z. and Markham, S. K. (2014). Product development as core competence: How formal product development practices differ for radical, more innovative, and incremental product innovations. Journal of Product Innovation Management. 31(2), 329-345.

Husted, B. (2005). Risk management, real options, and corporate social responsibility. Journal of Business Ethics. 60, 175-183.

Jennings, P. D. and Zandbergen, P. A. (1995). Ecologically sustainable organizations: An institutional approach. Academy of Management Review. 20(4), 1015-1052

Joyner, B. E. and Payne, D. (2002). Evolution and implementation: A study of values, business ethics and corporate social responsibility. Journal of Business Ethics. 41, 297-311.

Keough, K. A., Zimbardo, P. G. and Boyd, J. N. (1999). Who’s smoking, drinking, and using drugs? Time perspective as a predictor of substance use. Basic and Applied Social Psychology. 21(2), 149-164.

Klassen, R. and Vereecke, A., 2012. Social issues in supply chains: Capabilities link responsibility, risk (opportunity), and performance. International Journal of Production Economics, 140, 103-115.

Kleindorfer, P.R., Singhal K. and Van Wassenhove L.N., 2005. Sustainable Operations Management. Production and Operations Management, 14 (4), 482-492.

Kolk, A. (2012). Towards a sustainable coffee market: Paradoxes faced by a multinational company. Corporate Social Responsibility and Environmental Management. 19(2), 79-89.

Lankoski, L. (2008). Corporate responsibility activities and economic performance: a theory of why and how they are connected. Business Strategy and the Environment, 18 (7), 536-547.

Lee, H. L. (2010). Don't tweak your supply chain-rethink it end to end. Harvard Business Review. 88(10), 62-69.

Leopold, A. (1949). A Sand County Almanac. UK: Oxford University Press.

Lozano, R. (2008). Envisioning sustainability three-dimensionality. Journal of Cleaner Production. 16, 1838-1846. 
Lubin, D.A., and Esty, D.C. (2010). The sustainability imperative. Harvard Business Review, 88 (5), 42-50.

Maloni, M. and Brown, M. (2006). Corporate social responsibility in the supply chain: An application in the food industry. Journal of Business Ethics. 68 (1), 35-52.

Margolis, J. D. and Walsh, J. (2003). Misery loves companies: Rethinking social initiatives by business. Administrative Science Quarterly. 48(2), 268-305.

McKinsey (2013). The business of sustainability, McKinsey Report, Summer 2012.

Meier, K.J. and O’Toole, L.J. Jr. (2002). Public management and organizational performance: the effect of managerial quality. Journal of Policy Analysis \& Management. 21 (4), 629-643

Miles, M. B. and Huberman, M. A. (1994). Qualitative data analysis: a sourcebook of new methods. Thousand Oaks, CA: SAGE.

Orlitzky, M., Schmidt, F.L. and Rynes, S.L. (2003). Corporate social and financial performance: A meta-analysis. Organization Studies. 24(3), 403-441.

Owen, D.L., Swift, T.A., Humphrey, C. and Bowerman, M. (2000). The new social audits: accountability, managerial capture or the agenda of social champions? European Accounting Review. 9(1), 81-98.

Owen, D.L., Swift, T. and Hunt K. (2001). Questioning the role of stakeholder engagement in social and ethical accounting, auditing and reporting. Accounting Forum. 25(3), 264-282.

Pagell, M. and Gobeli, D. (2009). How plant managers' experiences and attitudes toward sustainability relate to operational performance. Production and operations management. 18 (3), 278-299

Pagell, M. and Shevchenko, A. (2014). Why research in sustainable supply chain management should have no future. Journal of Supply Chain Management. 50 (1).

Pinkse, J. and Kolk, A. (2010). Challenges and trade-offs in corporate innovation for climate change. Business Strategy and the Environment. 19(4), 261-272.

Porter, M.E. and Kramer, M.R. (2006). The link between competitive advantage and corporate social responsibility. Harvard Business Review. December, 1-24.

Prajogo, D. and Lai, K.H. (2014). The diffusion of environmental management system and its effect on environmental management practices. International Journal of Operations \& Production Management. 34(5), 565 - 585.

Rugman, A.M. and Verbeke, A. (1998). Corporate strategies and environmental 
regulations: an organizing framework. Strategic Management Journal. 19, 363-375.

Sadler-Smith, E. (2013). Toward organizational environmental virtuousness. Journal of Applied behavioural Science. 49 (1), 123-148.

Seuring, S. and Muller, M. (2008). From a literature review to a conceptual framework for sustainable supply chain management, Journal of Cleaner Production. 16(15), 1699-1710.

Singhapakdi, A., Vitell, S., Rallapalli, K. and Kraft, K. (1996). The perceived role of ethics and social responsibility: A scale development. Journal of Business Ethics. 15, $1131-1140$.

Slawinski, N. and Bansal, P. (2012). A Matter of Time: The Temporal Perspectives of Organizational Responses to Climate Change. Organization Studies. 33(11), 15371563.

Steurer, R. and Konrad, A. (2009). Business-society relations in Central-Eastern and Western Europe: How those who lead in sustainability reporting bridge the gap in corporate (social) responsibility. Scandinavian Journal of Management. 25 (1), 23-36.

Strauss, A. L. and Corbin, J. M. (1990). Basics of qualitative research. Techniques and procedures for developing grounded theory. SAGE Publications, Inc. Thousand Oaks, CA.

Tan, J. and Peng, M.W. (2003). Organizational slack and firm performance during economic transitions: two studies from an emerging economy. Strategic Management Journal. 24(13), 1249-1263.

Turban, D.B. and Greening, D.W. (1997). Corporate social performance and organisational attractiveness. Academy of Management Journal. 40, 658-672.

Vachon, S. and Mao, Z. (2008). Linking supply chain strength to sustainable development: a country-level analysis. Journal of Cleaner Production. 16 (15), 15521567.

Wellington, F., Bradley, R., Childs, B., Rigdon, C. and Pershing, J. (2007). Scaling up: Global technology deployment to stabilize emissions. World Resources Institute: Washington, DC.

Winn, M., Pinkse, J. and Illge, L. (2012). Case studies on trade-offs in corporate sustainability. Corporate Social Responsibility and Environmental Management, 19(2), 63-68.

Wolf, J. (2014). The relationship between sustainable supply chain management, 
stakeholder pressure and corporate sustainability performance. Journal of Business Ethics. 119, 317-328.

World Commission on Environment and Development (1987). Our common future. Oxford University Press, Oxford, UK.

Wu, Z. and Pagell, M. (2011). Balancing priorities: Decision-making in sustainable supply chain management. Journal of Operations Management. 29(6), 577-590.

Yin, R.K, 1994. Case study research: Design and methods, Sage Publications, Thousand Oaks, CA. 